\title{
In Vitro Monitoring of Time and Dose Dependent Cytotoxicity of Aminated Nanoparticles using Raman Spectroscopy
}

\author{
Esen Efeoglu \\ Technological University Dublin \\ Alan Casey \\ Technological University Dublin, alan.casey@tudublin.ie \\ Hugh Byrne \\ Technological University Dublin, hugh.byrne@tudublin.ie
}

Follow this and additional works at: https://arrow.tudublin.ie/biophonart

Part of the Biological and Chemical Physics Commons, Other Biochemistry, Biophysics, and Structural Biology Commons, and the Other Pharmacology, Toxicology and Environmental Health Commons

\section{Recommended Citation}

Efeoglu, E. Casey, A. \& Byrne, H.J. (2016) In vitro Monitoring of Time and Dose Dependent Cytotoxicity of Aminated Nanoparticles using Raman Spectroscopy", Analyst, 141, 5417-5431 (2016),

This Article is brought to you for free and open access by the DIT Biophotonics and Imaging at ARROW@TU Dublin. It has been accepted for inclusion in Articles by an authorized administrator of ARROW@TU Dublin. For more information, please contact arrow.admin@tudublin.ie, aisling.coyne@tudublin.ie,gerard.connolly@tudublin.ie. Funder: SFI 


\title{
In vitro Monitoring of Time and Dose Dependent Cytotoxicity of Aminated Nanoparticles using Raman Spectroscopy
}

\author{
Esen Efeoglu ${ }^{1,2, *}$, Alan Casey ${ }^{2}$, Hugh J. Byrne ${ }^{2}$ \\ ${ }^{1}$ School of Physics, Dublin Institute of Technology, Kevin Street, Dublin 2, Ireland \\ ${ }^{2}$ FOCAS Research Institute, Dublin Institute of Technology, Kevin Street, Dublin 2, Ireland \\ *Corresponding Author: esen.efeoglu@mydit.ie
}

\begin{abstract}
Investigation of possible adverse health effects of nanomaterials, in a rapid multi-parametric fashion, has become increasingly important, due to their increased production and potential uses in a wide range of application areas, from cosmetics to pharmaceutics. Although conventional in-vitro cytotoxicological techniques provide valuable information about the particle toxicity, the importance of gaining high content information in a single assay with the analysis of multiple parameters in a non-invasive and label-free way is still one of the biggest challenges in nanotoxicology. As a vibrational spectroscopic technique, the power of Raman spectroscopy for the analysis of cells, tissues and also nanoparticle localization within cells has been shown previously. In this study, the ability of Raman spectroscopy to fingerprint the dose and time dependent cellular responses and effect of cytotoxic events on biochemical constituents of the cells is monitored. A549 human lung carcinoma cells and aminated polystyrene nanoparticles (PS- $\left.\mathrm{NH}_{2}\right)$ are used as a model cell line and nanoparticle, respectively. Following the determination of cellular responses in the presence of toxic PS$\mathrm{NH}_{2}$ by using conventional cellular assays, Alamar Blue (AB) and (3-(4,5-Dimethylthiazol-2-
\end{abstract}


yl)-2,5diphenyltetrazoliumbromid (MTT), and calculation of $\mathrm{EC}_{50}$ values for both assays, Raman spectroscopy was employed at response related doses and time points. Multiple point spectra from the cytoplasm, nucleus and nucleolus of 20 cells were acquired using Raman spectroscopy for each exposure dose and timepoint. Unsupervised principle components analysis (PCA) was applied to the Raman data sets for the comparison of exposed and unexposed cells as well as different exposure doses and times. The study shows the ability of Raman spectroscopy to provide information about cellular responses at different particle concentrations and exposure times with the aid of multivariate analysis. In the chosen range of concentrations, the most significant changes were observed in the cytoplasm for both time dependent and dose dependent cases due to the route of endocytosis The Raman spectral markers for lipidosis, ROS formation and oxidative stress related biochemical damage are determined and correlated with exposure dose and time, and the responses are correlated with conventional cytotoxicity assays.

Keywords: Nanotoxicology, Raman spectroscopy, aminated polystyrene nanoparticles, in vitro screening, dose-dependent toxicity, time-dependent toxicity, Label free imaging 


\section{Introduction}

The growing interest and research in nanoscience and nanotechnology has introduced a plethora of nanomaterials into human life. More than 1600 products of nanotechnology have already found their place in the market, ranging from cosmetics to pharmaceutics (more information about nanotechnology based products can be found at http://www.nanotechproject.org/) ${ }^{1}$. From their production, to use and disposal by consumers, nanomaterials interact with living systems and the environment via different exposure routes. Due to their size, different surface properties and reactivity, related to their physicochemical properties, these novel materials can easily interact with biological systems. The emergence of Nanoscience and Nanotechnology has therefore given rise to the fields of Nanotoxicology ${ }^{2}$ and Nanomedicine ${ }^{3}$. Nanotoxicology mainly deals with the possible adverse biological effects of nanomaterials for humans and ultimately the environment ${ }^{4}$. The Organisation for Economic Co-operation and Development (OECD) recommends established and commonly used protocols for nanotoxicological assessment ${ }^{5}$, such as cell viability tests (3-(4,5Dimethylthiazol-2-yl)-2,5diphenyltetrazoliumbromid (MTT), Neutral Red (NR) and Alamar Blue $(\mathrm{AB}))$. On the other hand, Nanomedicine promises new paradigms in targeted drug delivery, diagnostics and imaging ${ }^{6,7}$. However, direct visualisation of the nanomaterials within cells, and the resultant cellular responses remains a challenge.

Raman spectroscopy has origin in inelastic collision of photons with molecules and provides fingerprint information about the specimen under investigation ${ }^{8,9}$. Due to the nature of the technique, fingerprint information at a molecular level, easy sample preparation steps, narrow spectral bandwidth and minimal influence from the water, a natural component of biological samples, the technique has attracted interest for the analysis of biological structures. The applicability of Raman spectroscopy as a tool for analysis of cells, tissues and biofluids has

been demonstrated in recent years ${ }^{10-15}$. The technique has also been widely used for the 
analysis of cell-drug and cell-nanoparticle interactions at a sub-cellular level ${ }^{16-23}$. The study of Dorney et al. demonstrated the ability of Raman spectroscopy to identify and discriminate different subcellular regions as well as the presence of the nanoparticles within these regions ${ }^{14}$. Moreover, the study of Keating et al. demonstrated the importance of multivariate analysis techniques on huge Raman data sets to gain further information about cellnanoparticle localisation ${ }^{24}$. Also, the ability of the Raman spectroscopy to differentiate different cellular compartments, such as endosomes and lysosomes, as well as localisation of the nanoparticles in these compartments has been demonstrated ${ }^{15}$. For the case of Carbon Nanotubes, Knief et al. ${ }^{25}$ probed the correlation of Raman biospectroscopic markers with conventional cytotoxicity assays, indicating that Raman spectroscopy can potentially be employed as a single, label free assay to localise nanoparticles, identify trafficking mechanisms and evaluate nanoparticle toxicity. However, an extensive study of dose and time dependent cellular responses to nanoparticle exposure has not as yet been reported.

The toxicity of aminated PSNPs (PS-NH$)$ has been extensively studied by different research groups to determine the mode of interaction of these nanoparticles with different types of human cell lines by using conventional cytotoxic and microscopic techniques ${ }^{26-31}$. Polystyrene nanoparticles are taken up by most of the cell lines through endocytosis, which is accepted as the primary mechanism for nanomaterial uptake into the cells ${ }^{32}$. Basically, particles are taken up across the cell membrane by the formation of early endosomes which carry the nanoparticles to the lysosomes. After particles are engulfed by lysosomes, they are carried to the endoplasmic reticulum ${ }^{15,33,34}$. In the case of $\mathrm{PS}-\mathrm{NH}_{2}$, exposure of cells to the nanoparticles can induce toxicity due to the formation of Reactive oxygen species (ROS). The formation of ROS starts with the endocytosis of nanoparticles and continues throughout their trafficking within cells. The resultant oxidative stress causes the release of inflammatory factors and triggers apoptosis. Also, release of cationic nanoparticles into the cytosol due to 
endosomal or lysosomal rupture resulting from membrane damage allows nanoparticles to reach the mitochondria and cause a change in mitochondrial membrane potential, also initiating the apoptotic process $^{29}$. Aminated polystyrene particles induce cytotoxicity by triggering caspase mediated apoptotic pathways, even at low exposure doses, due to their cationic properties. Basically, pro-apoptotic Bcl-2 proteins are located on the mitochondrial membrane and cause the formation of holes which will release apoptogenic factors and trigger the caspase activity ${ }^{26,29,30,35}$. As the responses of cells to commercially available PS$\mathrm{NH}_{2}$ exposure in vitro have been extensively documented, they can serve as ideal model nanoparticles to explore the capabilities of Raman spectroscopy to monitor cellular responses.

In this study, the dose and time dependent cellular responses and effect of cytotoxic events on biochemical constituents of the cells are monitored using Raman spectroscopy. Aminated polystyrene nanoparticles (PS- $\mathrm{NH}_{2}$ ) are chosen as model nanoparticles due to their welldocumented cytotoxic mechanisms. Human lung adenocarcinoma (A549) cells were chosen for consistency with other studies ${ }^{15,26}$, which show common modes of action in a number of cell lines, and as they act as models for human exposure by inhalation. Cells were exposed to PS- $\mathrm{NH}_{2}$ in different doses and for different exposure times. In order to determine toxic effects of the PS- $\mathrm{NH}_{2}$ in A549 cells, the conventional cytotoxic assay, Alamar Blue was carried out for 4, 8, 12 and $24 \mathrm{hr}$ particle exposure. The 3-(4,5-dimethylthiazol-2-yl)-2,5diphenyltetrazolium bromide (MTT) assay was also used to determine cytotoxic effect of PS$\mathrm{NH}_{2}$ in A549 cells after $8 \mathrm{hr}$ particle exposure to compare the responses from different cytotoxicity assays. A549 cells were exposed to $2.5,5$ and $10 \mu \mathrm{M}$ concentrations of the PS$\mathrm{NH}_{2}$ for the evaluation of spectroscopic signatures of the dose-dependent toxic responses in the fingerprint region of the Raman spectrum. Also, cells were exposed to $2.5 \mu \mathrm{M}$ of PS- $\mathrm{NH}_{2}$ for $4,8,12$ and $24 \mathrm{hrs}$ for the assessment of toxicity related changes in biomolecules such as the proteins, lipids and nucleic acids. In order to elucidate the roles of different cellular 
regions and related toxic responses, Raman spectra were acquired from cytoplasm, nucleus and nucleolus. Raman datasets and unsupervised Principal Component analysis (PCA) was used for the elucidation and comparison of dose and time dependent biomolecular changes in the cells upon nanoparticle exposure.

\section{Materials and Methods}

\section{Nanoparticles}

$100 \mathrm{~nm}$ amine-modified and fluorescently labelled, latex type, polystyrene nanoparticles (PS$\mathrm{NH}_{2}$, Product Number: L9904) were chosen as model nanoparticles for this study and purchased from Sigma-Aldrich (Ireland). The peak excitation and emission wavelengths of the PS- $\mathrm{NH}_{2}$ are specified by the manufacturer as 481 and $644 \mathrm{~nm}$, respectively. The PS- $\mathrm{NH}_{2}$ were further characterised using a Malvern Zetasizer ZS to determine their size and surface potential in phosphate buffered saline (PBS) and cell culture medium. The nanoparticles were freshly prepared in pre-warmed cell culture medium containing supplements on the day of exposure.

\section{Cell Culture}

The human lung adenocarcinoma cell line, A549, was purchased from ATCC (ATTC. No: CCL-185) and cultured in Dulbecco's Modified Eagle's Medium Nutrient Mixture F-12 HAM (DMEM-F12) supplemented with 2mM L-glutamine and 10\% foetal bovine serum (FBS, Sigma Aldrich) at $37{ }^{\circ} \mathrm{C}$ in a humidified $5 \% \mathrm{CO}_{2}$ incubator. Cells were sub-cultured at three days intervals to $60 \%-70 \%$ confluency.

\section{Preparation of nanoparticle solutions}


The $\mathrm{PH}-\mathrm{NH}_{2}$ solutions for both Raman measurements and cytotoxicity assays were prepared to the desired concentrations from initial concentrations by diluting the nanoparticles directly in $10 \%$ FBS and 2mM L-glutamine supplied DMEM-F12.

\section{Cytotoxicity Assays and Determination of half-maximal effective concentration $\left(\mathbf{E C}_{50}\right)$}

Alamar Blue (AB) and 3-(4,5-dimethylthiazol-2-yl)-2,5-diphenyltetrazolium bromide (MTT) assays were used to evaluate dose and time dependent cytotoxicity responses of $100 \mathrm{~nm}$ PS$\mathrm{NH}_{2}$ in A549 cells. $\mathrm{AB}$ and MTT assays were purchased from Biosciences Ltd(IRL) and Sigma-Aldrich (Dublin, Ireland), respectively and both assays were carried out on the same 96-well plate (Nunc, Denmark) by following manufacturer's instructions. A549 cells were seeded onto 96 -well plates with densities of $1 \times 10^{5}$ cells $/ \mathrm{mL}$ and incubated at $37{ }^{\circ} \mathrm{C}$ in $5 \%$ $\mathrm{CO}_{2}$ for $24 \mathrm{hrs}$ for initial attachment and to achieve the desired confluency. PS- $\mathrm{NH}_{2}$ solutions were prepared in the concentration range from 40 to $0.3125 \mu \mathrm{M}$ by serial dilutions in prewarmed DMEM-F12 medium supplemented with 10\% FBS and 2mM L-glutamine. Following $24 \mathrm{hr}$ initial attachment, the medium was removed and cells were rinsed with 100 $\mu \mathrm{l} /$ well PBS. A549 cells were exposed to the range of $\mathrm{PS}-\mathrm{NH}_{2}$ concentrations for each of the time points, 4, 8, 12, 24 and $48 \mathrm{hr}$. 10\% Dimethyl sulfoxide (DMSO), prepared in cell culture medium, was used as a positive control. Six replicates of each different nanoparticle concentration, negative (A549 cells) and positive (DMSO) controls were used in each 96well plate and 3 independent experiments were used to evaluate cytotoxic response of the PS$\mathrm{NH}_{2}$ on A549 cells for both assays. After particle exposures, the cell medium containing nanoparticles was removed and cells were washed with PBS three times. AB/MTT solution was prepared in the ratio of $5 \%[\mathrm{v} / \mathrm{v}]$ solution of $\mathrm{AB}$ and $10 \%[\mathrm{v} / \mathrm{v}]$ of MTT dye in unsupplemented DMEM-F12. A $100 \mu \mathrm{l} /$ well of MTT/AB solution was added to A549 cells and they were incubated for $3 \mathrm{hrs}$ at $37{ }^{\circ} \mathrm{C}$ in $5 \% \mathrm{CO}_{2}$. A microplate reader (SpectraMax-M3, Molecular Devices, USA) was used to measure AB fluorescence emission at $595 \mathrm{~nm}$ 
(excitation/emission 540/595 nm, respectively). Following AB measurement, the cell medium containing AB and MTT is removed and cells were rinsed with PBS. $100 \mu \mathrm{l} /$ well of DMSO were added to the 96-well plates and plates were agitated at $200 \mathrm{rpm}$ for 10 mins. MTT absorbance was measured at $570 \mathrm{~nm}$ by using same plate reader system. The $\mathrm{EC}_{50}$ calculation was made by using a four parameter sigmoidal fit in SigmaPlot.

\section{Raman Spectroscopy}

Raman spectroscopy was used to monitor dose and time dependent changes of cellular constituents of A549 cells upon PS- $\mathrm{NH}_{2}$ exposure. Approximately 16000 cells per substrate were seeded onto $\mathrm{CaF}_{2}$ disks and incubated for $24 \mathrm{hrs}$ at $37{ }^{\circ} \mathrm{C}$ in $5 \% \mathrm{CO}_{2}$ for initial attachment. After initial attachment of the cells, cell medium was removed and cells were rinsed with PBS. The cell medium of A549 cells, which were used as control and will be referred to as unexposed cells throughout the study, was replaced with fresh $10 \%$ FBS and 2mM L-glutamine supplemented DMEM-F12. For the preparation of exposed cells, PS- $\mathrm{NH}_{2}$ solutions with concentrations of 2.5, 5 and $10 \mu \mathrm{M}$ were prepared in FBS and L-glutamine supplemented DMEM-F12 for the evaluation of dose dependent responses. A549 cells were exposed to the each concentration of PS-NH 2 for 8 hrs. Exposures to $2.5 \mu \mathrm{M}$ PS-NH 2 were used for the assessment of time-dependent cellular responses, at 4, 8, 12, 24 and $48 \mathrm{hrs}$. In parallel, unexposed cells were incubated in fresh medium at $37{ }^{\circ} \mathrm{C}$ in $5 \% \mathrm{CO}_{2}$ for periods equivalent to the $\mathrm{PS}-\mathrm{NH}_{2}$ exposure times. Following the particle exposures and incubation of unexposed cells, medium containing $\mathrm{PS}-\mathrm{NH}_{2}$ for exposed cells and cell medium for unexposed cells was removed and cells were washed with PBS thrice. 10\% formalin was used to fix cells for 10 mins. After fixation of cells, formalin was removed and cells were washed three times with distilled and sterilised water. Throughout the study, Raman measurements were acquired by using water-immersion objective. Therefore, after fixation and washing steps, cells were kept in water and spectra were acquired in water. 
A Horiba Jobin-Yvon LabRAM HR800 spectrometer, equipped with a $785 \mathrm{~nm}$ diode laser as source was used throughout the study. All measurements were acquired in water by using a x100 water immersion objective (LUMPlanF1, Olympus, N.A. 1). The spectrometer was calibrated to the $520.7 \mathrm{~cm}^{-1}$ line of silicon prior to spectral acquisition. A 300 lines per mm grating was chosen, which provides approximately $1.5 \mathrm{~cm}^{-1}$ per pixel spectral dispersion. A $100 \mu \mathrm{m}$ confocal pinhole was used for all measurements. The spectra were dispersed onto a 16 bit dynamic range Peltier cooled CCD detector. Point spectra from the cytoplasm, nucleus and nucleolus of 20 cells were acquired for each dose and exposure time. The spectral range from 400 to $1800 \mathrm{~cm}^{-1}$, the so-called fingerprint region, was chosen and spectra were acquired for $2 \times 30$ seconds at each spot. Unexposed cells were used as control for comparisons of the different doses and exposure times.

\section{Data Analysis}

Raman data sets were transferred to Matlab (Mathworks, USA) for data analysis. Preprocessing was carried out in the same data analysis platform to improve spectral quality. For pre-processing, first, a mild smoothing was applied to data sets by using Savitsky-Golay filter ( $3^{\text {rd }}$ order and 9 points). Classical Least Squares (CLS) analysis was employed to minimize contributions from the background which is dominantly water in the immersion geometry ${ }^{12,36}$. Spectra were vector normalized following smoothing and background subtraction. Principle Component Analysis (PCA) was applied to pre-processed Raman data sets to differentiate the spectral changes in fingerprint region of the nucleus, nucleolus and cytoplasm upon PS- $\mathrm{NH}_{2}$ exposure. 


\section{Results and Discussion}

The well-established and commonly used cytotoxicity assay, AB, was carried out to determine the dose and time dependent toxic effect of $\mathrm{PS}-\mathrm{NH}_{2}$ on $\mathrm{A} 549$ cells ${ }^{37-39}$. Figure 1.I shows the plots of cytotoxic response of $\mathrm{PS}-\mathrm{NH}_{2}$ on A549 cells determined by the AB assay. Half-maximal concentration for cellular viability, $\mathrm{EC}_{50}$, values relating to the different particle exposure times were calculated in SigmaPlot by a four parameter sigmoidal fit. For 4 hr PS- $\mathrm{NH}_{2}$ exposure, the $\mathrm{EC}_{50}$ value was calculated to be $20 \pm 1 \mu \mathrm{M}$. After $12 \mathrm{hr}$ particle exposure, the $\mathrm{EC}_{50}$ value was decreased to $11 \pm 4 \mu \mathrm{M}$. For $24 \mathrm{hr}$ exposure of A549 cells to the PS- $\mathrm{NH}_{2}$, a median cytotoxic effect at a concentration of $10 \pm 2 \mu \mathrm{M}$ was observed, while when cells were exposed to the PS- $\mathrm{NH}_{2}$ for $48 \mathrm{hrs}$, the $\mathrm{EC}_{50}$ value is calculated as $2.8 \pm 0.2 \mu \mathrm{M}$. The degree of toxicity is inversely related to the $\mathrm{EC}_{50}{ }^{40}$ and thus, when all exposure times are compared, the cytotoxicity of PS- $\mathrm{NH}_{2}$ progressively increases from $4 \mathrm{hr}$ to $48 \mathrm{hr}$ exposure.
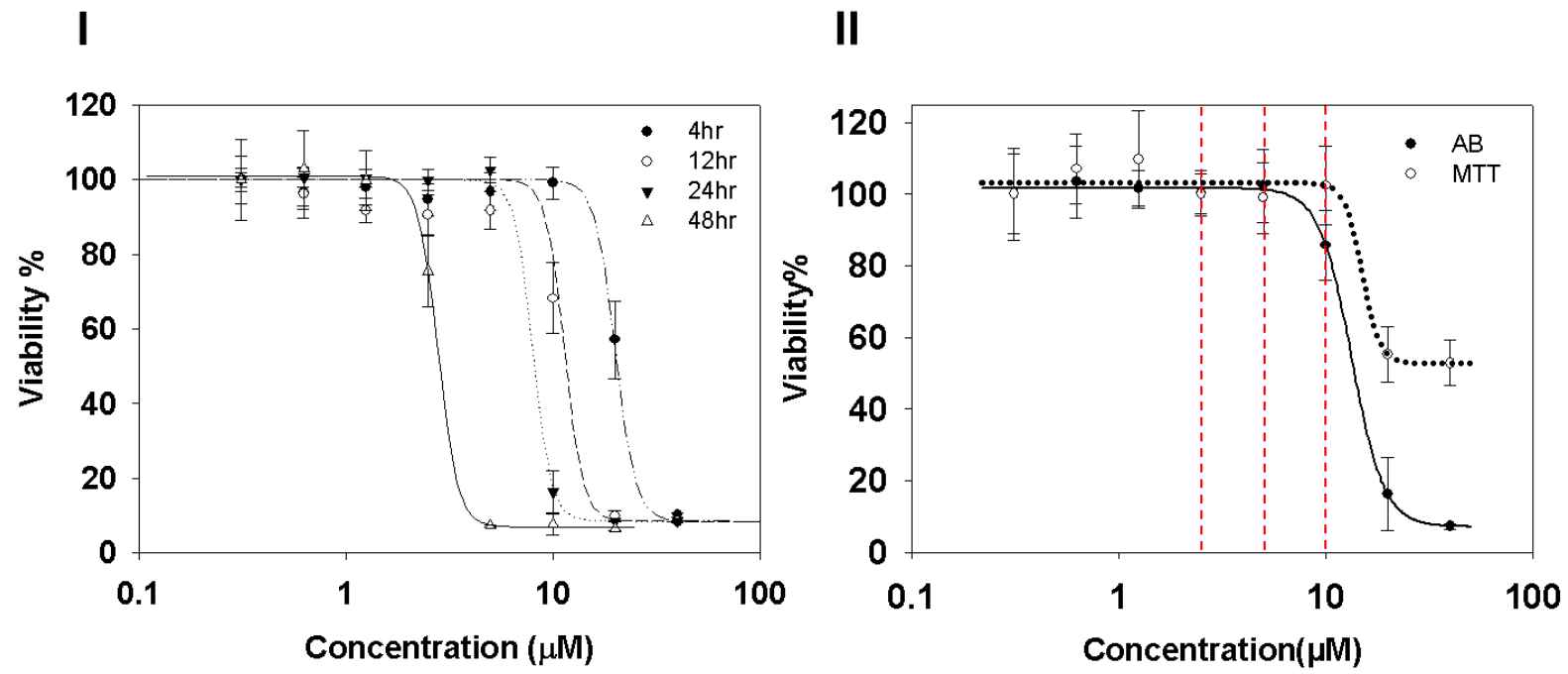

Figure 1. I) Cytotoxicity of $40 \mathrm{~nm}$ amine-modified polystyrene nanoparticles $\left(\mathrm{PS}-\mathrm{NH}_{2}\right)$ after 4, 12, 24 and $48 \mathrm{hr}$ exposures determined by the Alamar Blue assay. II) Cytotoxicity of 40 nm amine-modified polystyrene nanoparticles $\left(\mathrm{PS}-\mathrm{NH}_{2}\right)$ after 8 exposure determined by the 
Alamar Blue and MTT assays. The concentrations $(2.5,5$ and $10 \mu \mathrm{M})$ which are used throughout the study are indicated by red dashed lines. Data are expressed as $\%$ of control mean \pm SD of three independent experiments.

As an alternative and complementary measure of cytoxic response, the MTT assay was also employed to monitor the toxic response of A549 cells to $\mathrm{PS}-\mathrm{NH}_{2}$ exposure. Figure 1.II compares the dose dependent responses for $8 \mathrm{hr}$ PS- $\mathrm{NH}_{2}$ exposure from the two assays, MTT and $\mathrm{AB} . \mathrm{EC}_{50}$ values for both assays were observed similar to each other which are $13 \pm 1$ and $15 \pm 5 \mu \mathrm{M}$ for $\mathrm{AB}$ and $\mathrm{MTT}$, respectively. Although $\mathrm{EC}_{50}$ values were calculated to be similar, the difference in the underlying mechanism of toxicity changes according to concentration of PS- $\mathrm{NH}_{2}$. The increasing concentrations of PS- $\mathrm{NH}_{2}$ cause a rapid decrease in cell viability when it is determined by the AB assay, compared to that which is determined by MTT after 8hr exposure. For this reason, significantly different toxicological profiles can be obtained from well-established cytotoxicity assays due to the limitations of specific colorimetric label based assays.

The dose and time dependent cytotoxic response of a cytotoxicological assay reflects a complex cascade of events, triggered by endocytosis of the nanoparticles, giving rise to subsequent oxidative stress, inflammatory responses, apoptosis and cell death, as described for example by Maher et al. ${ }^{41}$. Each cytotoxicity assay measures the toxic response of cells in different ways, and the relative sensitivity of the assay depends on the events in the cascade to which it is sensitive. $\mathrm{AB}$ is a measure of overall cellular activity as measured by the transformation of Rezazurin Sodium Salt (weak fluorescence) into Resofurin Sodium salt which has a strong fluorescence. Although the exact mechanism of the reduction reaction is unknown, as there are multiple cellular sites of conversion, $A B$ assay provides valuable information about the overall activity of the cell population ${ }^{38,39,42,43}$. On the other hand, the MTT assay measures the cell activity based on formazan product formation which relates to 
the mitochondrial activity of cells ${ }^{44}$. In cases such as cellular exposure to poly (amido amine) (PAMAM) dendrimer nanoparticles, in which endosomolysis leads to translocation of the nanoparticles to the mitochondria, MTT is seen to be significantly more sensitive than $A B$, which measures the subsequent change to the cytosolic activity ${ }^{45}$. The formation of ROS inside the cell is regulated by different factors such as protective enzymes and antioxidant mechanisms. The ROS formation and cell protection mechanism works through the cross-talk between cytosolic events and mitochondrial events upon the presence of ROS. In the case of PS- $\mathrm{NH}_{2}$ exposure, the nanoparticles are trafficked from endosomes to lysosomes, and the toxic insult is first manifest through generation of ROS in the cytosol (around cell membrane and lysosomes), which subsequently impacts on the mitochondria ${ }^{46,47}$.

Although cytotoxicity assays such as AB, Neutral Red, and those based on tetrazolium salts (MTT, MTS, WST-1), provide valuable information about the toxic effect of material the under investigation, these techniques are not a definitive measure of cell viability and provide little information about the mechanism of action of the toxicants in terms of molecular determinants and pathways. In contrast, as a label free technique, Raman spectroscopy can potentially provide a high content spectroscopic profile of the cells and complete biochemical response at a given exposure time and dose (as illustrated by the mean spectra of the subcellular regions of the unexposed cell population, Supplementary Figure S1). The dose dependent cytotoxicity measurements serve as a range finding test for Raman analysis.

Figure 2 shows the PCA of spectra corresponding to cytoplasm, nucleus and nucleolus of the 8hr unexposed control and $10 \mu \mathrm{M}$ PS- $\mathrm{NH}_{2}$ exposed cells. Although this dose is less than the $\mathrm{EC}_{50}$ for both assays at this time point, it induces a significant reduction in viability, as registered using the $\mathrm{AB}$ assay (Figure 1.II). Figure 2.I shows the scatter plots of PCA and the data sets relating to unexposed and exposed cells are indicated with closed circles and open circles, respectively and coded with colours according to the different cellular regions. 
Cytoplasm, nucleus and nucleolus are indicated with red, green and blue, respectively. The same colour coding system is used for exposed cells, but with the use of open circles. The spectra corresponding to the nuclear areas (nucleus and nucleolus) and cytoplasm are clearly differentiated for both exposed and unexposed cells according to PC1, which represents the most significant variance (46\%) among the data, originating from biochemical differences between the combined nuclear area and cytoplasm. The spectra relating to the cytoplasm of both exposed and unexposed cells score negatively according to Loading 1 ( $\mathrm{PC} 1<0)$, while nuclear and nucleolar spectra score positively according to Loading 1 (PC1 $\geq 0)$. PC2 gives information about the second highest variance (16\%) among the data sets, and differentiates each region for exposed and unexposed cells. For all cellular regions, exposed cells are clearly differentiated from unexposed cells, indicating that the spectral differences are larger than the intrinsic variability of each region, and score positively according to PC2 (indicated by open circles) while unexposed cells score negatively $(\mathrm{PC} 2<0)$ (indicated by closed circles). 


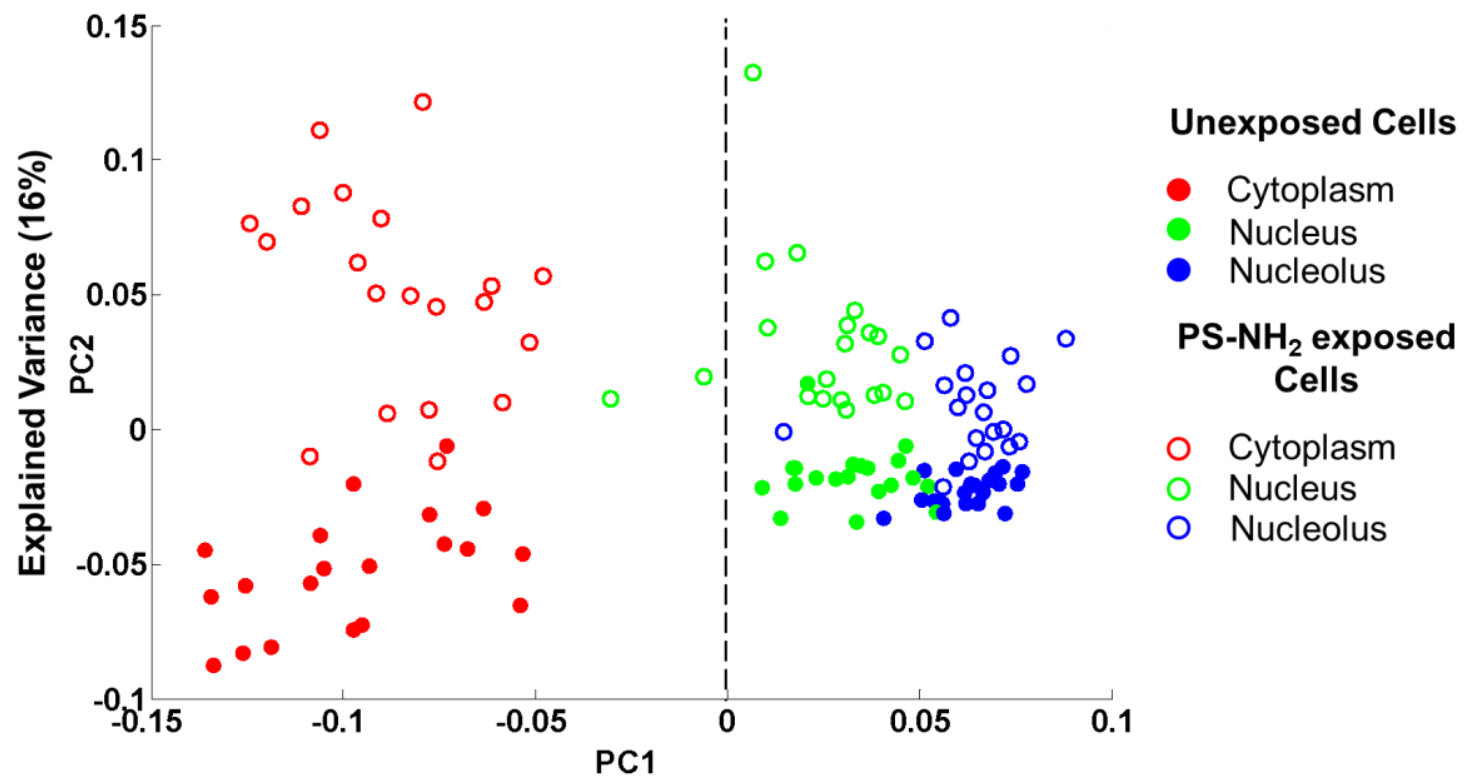

Explained Variance (46\%)

II

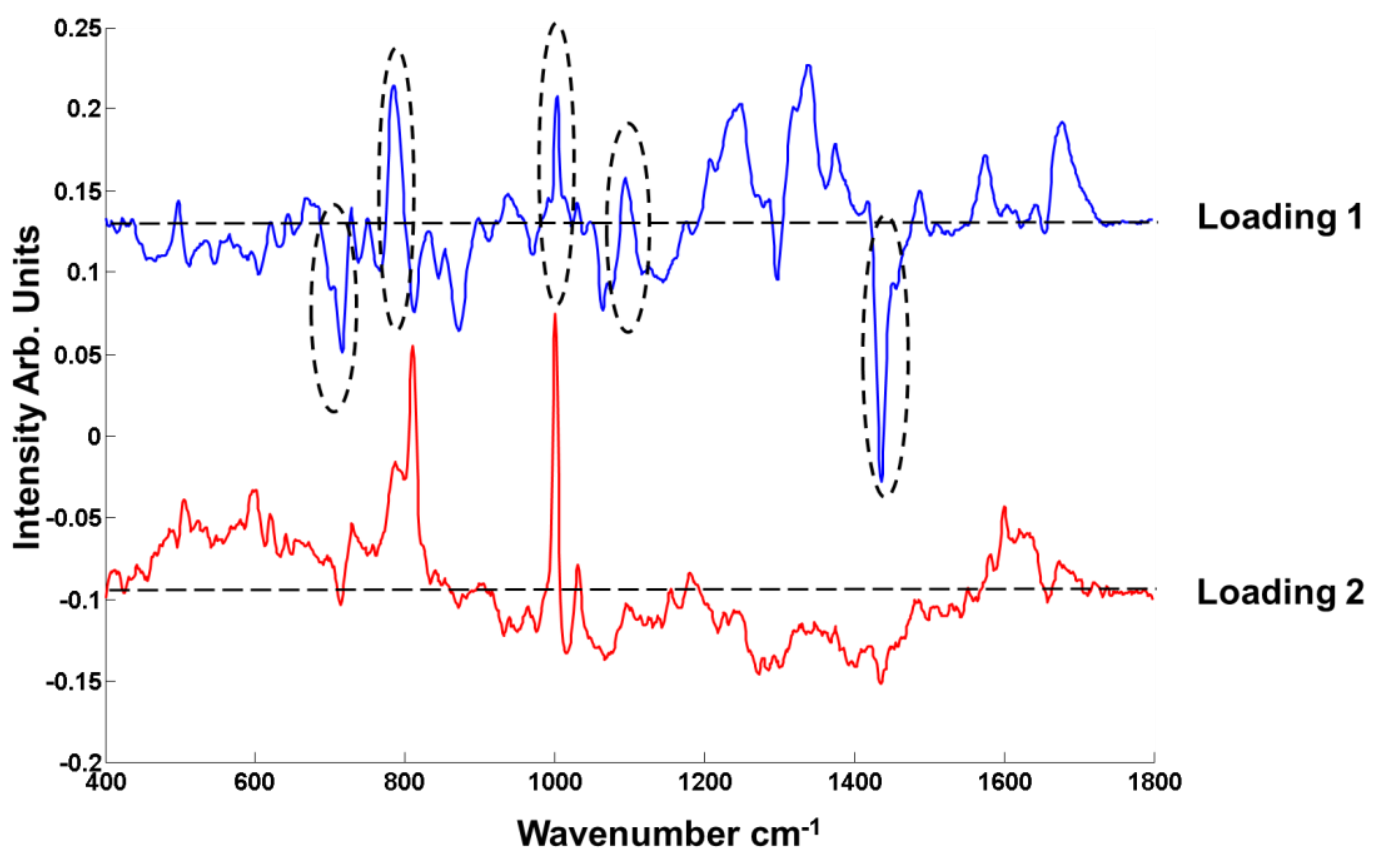

Figure 2. I) Scatter plot of the PCA of spectra corresponding to cytoplasm, nucleus and nucleolus of the (8hr) unexposed and PS- $\mathrm{NH}_{2}$ exposed cells for $10 \mu \mathrm{M}$ concentration of nanoparticles. Different cellular regions are coded as follows; red for cytoplasm, green for nucleus and blue for nucleolus. Exposed and unexposed cells are indicated by open circles 
and closed circles, respectively. II) First 2 loadings of PC analysis; loadings are offset for clarity and the dotted line represents the zero ' 0 ' point for each loading. In loading 1 , notable bands which are used to differentiate the nuclear region from cytoplasm are indicated by black dashed outlines.

Figure 2.II shows the first two loadings of the PCA, corresponding to all regions of exposed and unexposed cells. As seen in Figure 2.I, exposed and unexposed cells differentiate from each other based on the differences in biochemical composition of nuclear regions and cytoplasm according to PC1. The spectra of the nuclear area of the cell, which is composed of nucleus and nucleolus, score positively, while spectra corresponding to cytoplasm score negatively, according to PC1, for both exposed and unexposed cells. For this reason, the positive features of loading 1 are dominated by nuclear and nucleolar related bands, while negative features relate to the cytoplasm. The most dominant features which are used to differentiate the nuclear area (nucleus and nucleolus) and cytoplasm, the positive features at $785,1003,1094 \mathrm{~cm}^{-1}$ and the negative features $\sim 719,1437 \mathrm{~cm}^{-1}$, are indicated with black outlines in Figure 2.II. Amongst the positive features, the bands at $\sim 785 \mathrm{~cm}^{-1}$ (Nucleic acids uracil $(\mathrm{U})$, thymine $(\mathrm{T})$, cytosine $(\mathrm{C})$ ring breathing modes in the DNA/RNA bases, O-P-O backbone), 1003 (phenylalanine(Phe)), $1094 \mathrm{~cm}^{-1}$ (DNA), $1248 \mathrm{~cm}^{-1}$ (Guanine(G) and cytosine $\left(\mathrm{NH}_{2}\right)$, Amide III), $1339 \mathrm{~cm}^{-1}$ (Phe, tyrosine(Tyr), nucleic acid), $1373 \mathrm{~cm}^{-1} \mathrm{~T}, \mathrm{G}$, adenine(A) bases of deoxyribonucleic acid (DNA) and ribonucleic acid (RNA)), $1575 \mathrm{~cm}^{-1}$ (G, A of nucleic acids) and $1678 \mathrm{~cm}^{-1}$ (bound or free NAHD, Amide I region) indicate the predominance of nucleic acids and proteins which are abundant in the nuclear area ${ }^{48-50}$. On the other hand, the dominant negative features include those at $\sim 719 \mathrm{~cm}^{-1}$ (membrane phospholipid head, phosphatidylcholine), $873 \mathrm{~cm}^{-1}$ (hydroxyproline, tryptophan (Trp)), 1064 $\mathrm{cm}^{-1}$ (acyl chains, $\mathrm{v}(\mathrm{C}-\mathrm{C})$ ), $1078 \mathrm{~cm}^{-1}$ (phospholipids), $1298 \mathrm{~cm}^{-1}$ (fatty acids) and $1437 \mathrm{~cm}^{-1}$ (Lipids, acyl chains, $\mathrm{CH}_{2}$ deformation), which are more characteristic of the lipid rich 
cytoplasm. Unexposed and exposed cells are differentiated mainly according to loading 2, as seen in Figure 2.II. Although there are some contributions to the loading 2 from $\mathrm{PS}-\mathrm{NH}_{2}$ in the positive features, cells exposed for $8 \mathrm{hr}$ to $10 \mu \mathrm{M}$ of $\mathrm{PS}-\mathrm{NH}_{2}$ are mainly differentiated from the unexposed cells by increases in the intensities of nucleic acid bands at $785 \mathrm{~cm}^{-1}$ and $810 \mathrm{~cm}^{-1}$ (RNA, O-P-O stretching) $\mathrm{cm}^{-1}$ and protein Amide I band at $1604 \mathrm{~cm}^{-1}$. For loading 2, the bands derived from PS-NH 2 at $620,1003,1030$ and $1600 \mathrm{~cm}^{-1}$ have been excluded from discussion.

Polystyrene nanoparticles are taken into the cells by the mechanism known as endocytosis. Previous studies have confirmed that the polystyrene nanoparticles (PS-COOH) are taken up into endosomes and carried to lysosomes ${ }^{15,26,51-53}$. Most of the nanoparticles are observed in lysosomes after $8 \mathrm{hr}$ particle exposure. For this reason, after shorter exposure times, for example $8 \mathrm{hr}$, most of the cytotoxic responses can be attributed to changes in the cytoplasm and due to a cascade of processes including ROS formation, mitochondrial damage and lipidosis $^{26,41}$, but notably, the nucleus and nucleolus are not affected as much as cytoplasm. In order to better identify changes in the biomolecular composition of the cytoplasm, nucleus and nucleolus upon PS- $\mathrm{NH}_{2}$ exposure, the mean spectra of particle exposed cells and unexposed cells were obtained and the spectral differences for each individual cellular region are evaluated by subtracting the mean spectra of exposed cells from the mean spectra of unexposed cells (Figure 3). When the mean spectra of cytoplasm, nucleus and nucleolus are analysed, the most significant changes are observed in the cytoplasm (red) of exposed cells compared to the corresponding control, as seen in Figure 3. For all cellular regions, some contributions from the PS- $\mathrm{NH}_{2}$ are observed in PS- $\mathrm{NH}_{2}$ exposed cells and the bands related to PS are highlighted with grey and excluded from band assignments. 


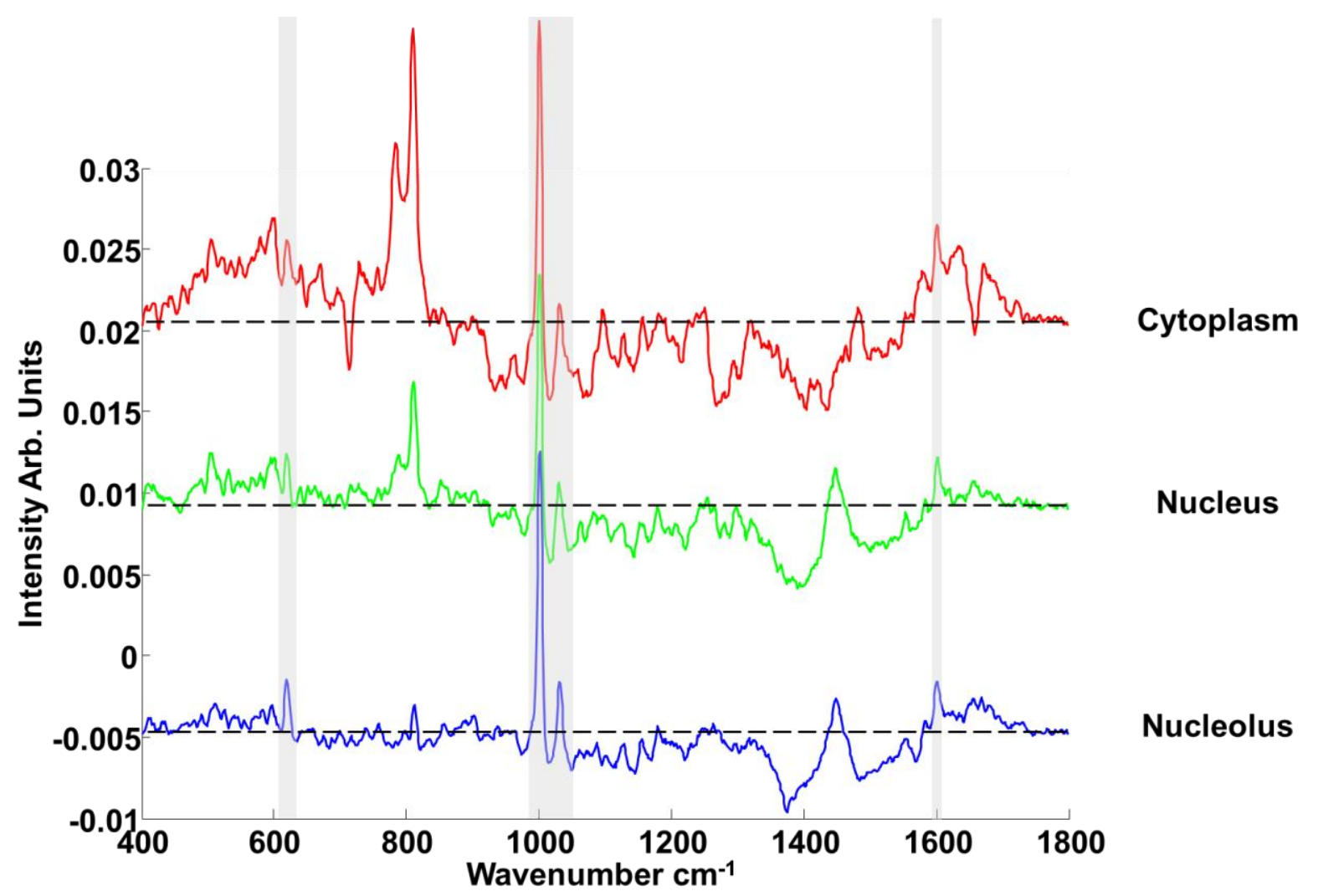

Figure 3. Mean difference spectra of cytoplasm (red), nucleus (green) and nucleolus (blue) obtained by subtraction of mean spectra of $8 \mathrm{hr}$ PS- $\mathrm{NH}_{2}$ exposed cells from mean spectra of unexposed cells. The spectra are offset for clarity, the dashed line indicating the zero point. The bands related to PS are indicated with grey highlights.

Cellular events as a result of nanoparticle exposure to, and uptake of, a toxicant cause the production, consumption and/or damage of biochemical constituents inside the cells. The changes in the biochemical constituents are reflected in the Raman spectral data sets and can be used to identify different cellular events. When cells are exposed to $10 \mu \mathrm{M}$ PS- $\mathrm{NH}_{2}$ for 8 hr, the most significant changes are observed in the cytoplasm, as seen in Figure 3. The intensity of the bands at 785 and $810 \mathrm{~cm}^{-1}$ become significantly higher compared to the controls. The band at $785 \mathrm{~cm}^{-1}$ can be attributed to the ring breathing mode of nucleic acid bases (U, T and C) or O-P-O backbone stretching of nucleic acids, as so can be attributed to either RNA or DNA ${ }^{46-48}$. The band at $810 \mathrm{~cm}^{-1}$ is attributed to RNA structures ${ }^{54,55}$ and relates 
to asymmetric stretching of the sugar-phosphate diester. The presence of 785 and $810 \mathrm{~cm}^{-1}$ bands in Raman spectra of the cytoplasm has been examined in the study of Ghita et al. ${ }^{56}$, which showed that an increase of the RNA bands during cell differentiation can be attributed to repressed translation of mRNAs and increasing amounts of noncoding RNAs in the cytoplasm. As seen in Figure 3, upon PS-NH 2 exposure, the band at $810 \mathrm{~cm}^{-1}$ shows a significant increase compared to its control with a concomitant increase in the band at 785 $\mathrm{cm}^{-1}$, while control cells did not show any significant band at $810 \mathrm{~cm}^{-1}$ for cytoplasm (Supplementary Figure S2).

The exposure of cells to toxic PS- $\mathrm{NH}_{2}$ is known to result in ROS formation ${ }^{57}$. Increased ROS levels in the cell first impacts on the mitochondria and causes the mediation of cytotoxic effects and release of pro-apoptotic factors with increasing production of mitochondrial $\operatorname{ROS}^{58}$, which in turn can cause deformation of cytoplasmic RNAs which generally localises in close proximity to the mitochondria and results in repression of translation and accumulation of noncoding RNAs in the cytoplasm of exposed cells. The role of oxidative stress in the repression of mRNA translation has been shown previously ${ }^{59-61}$. For this reason, an increase in the intensity of the $810 \mathrm{~cm}^{-1}$ band in the cytoplasm can be attributed to changes in RNA content, as a result of oxidative stress and can be used as a mitochondrial damage marker in a label-free way. Although the band at $785 \mathrm{~cm}^{-1}$ can be attributed to either DNA or RNA, the concomitant increase in the $810 \mathrm{~cm}^{-1}$ for short exposure times is consistent with a primary attribution of increased RNA accumulation in cytoplasm.

The cytoplasmic responses upon particle exposure are further explored according to their correlation with the concentration of toxicant. The effect of $\mathrm{PS}-\mathrm{NH}_{2}$ exposure on A549 cells was also monitored using intermediate $(5 \mu \mathrm{M})$ and sub-lethal doses $(2.5 \mu \mathrm{M})$, for $8 \mathrm{hrs}$. PCA clearly differentiates unexposed and exposed cells according to PC1 for all exposure doses. 
Scatter plots of unexposed and exposed cells for each exposure dose are provided in Supplementary Figure S3, and a representative example of scatter plot of cytoplasm of exposed and unexposed cells for $10 \mu \mathrm{M}$ PS-NH 2 is shown in Figure 4.I. The respective loadings for the cytoplasmic regions of 2.5, 5 and $10 \mu \mathrm{M}$ are shown in Figure 4.II.

For $10 \mu \mathrm{M}$ PS- $\mathrm{NH}_{2}$, which is close to the $\mathrm{EC}_{50}$ value for $\mathrm{AB}$, exposed cells are differentiated from unexposed cells due to a significant increase of the intensity of nucleic acid bands represented by positive features of loading $1\left(785\right.$ and $\left.810 \mathrm{~cm}^{-1}\right)$, which can also be seen in the difference of mean spectra of exposed and unexposed cells (Figure 3). Notably, the changes in this region are seen to evolve monotonically with exposure dose (Figure 4, Figure S4), confirming a direct correlation between the changes in nucleic acid spectral signatures and particle exposure. 


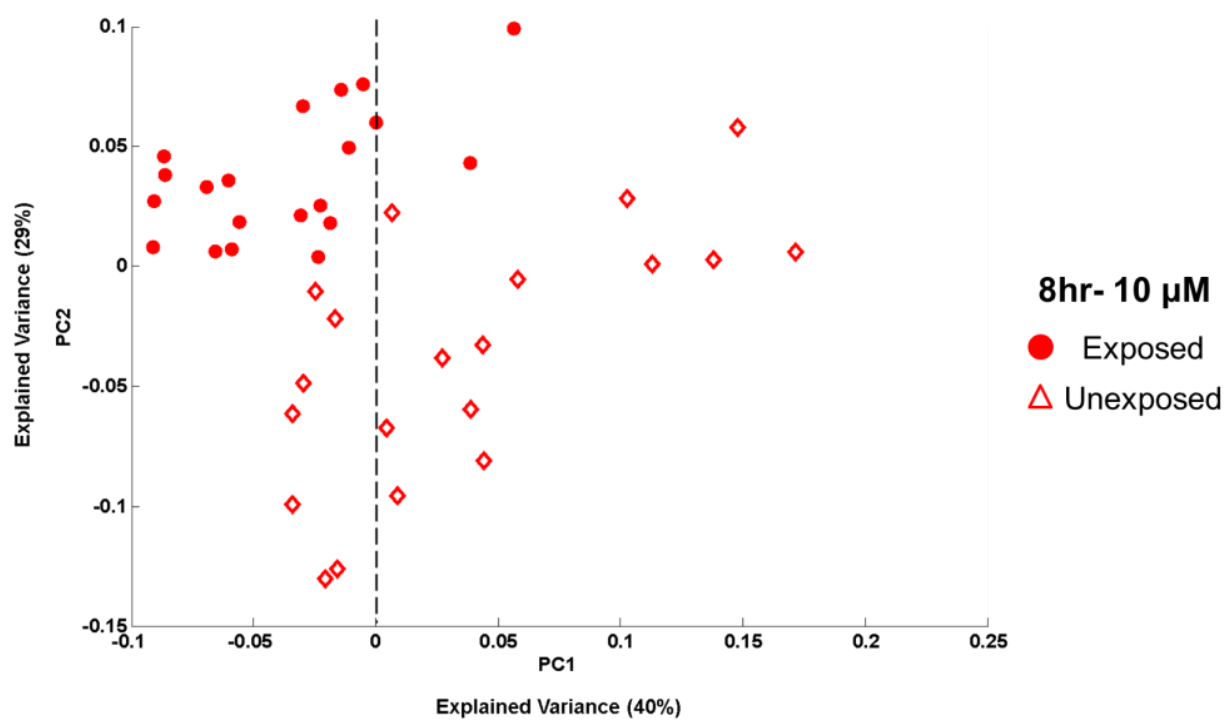

II

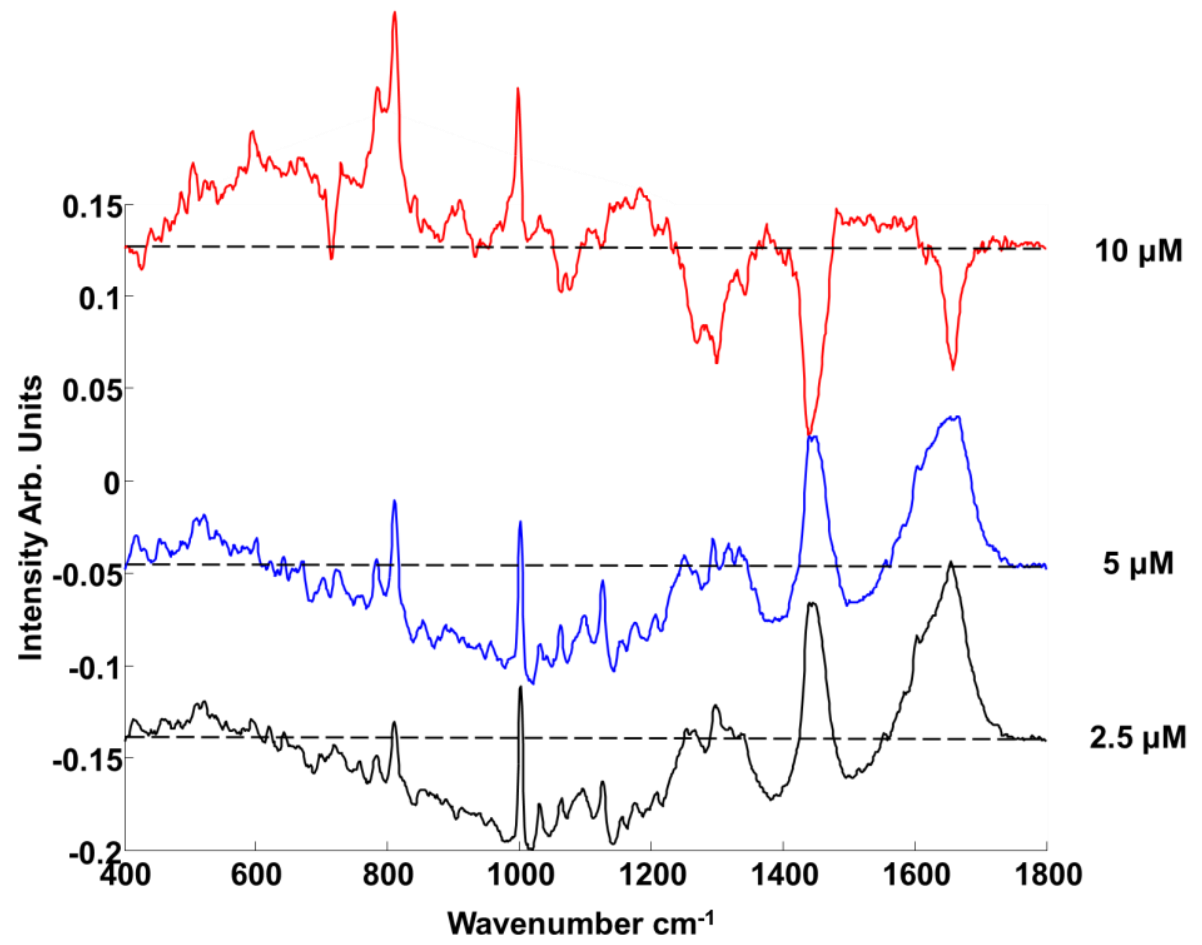

Figure 4. I) Scatter plot of the PCA of spectra corresponding to cytoplasm of the unexposed cells (closed circles) and cells exposed to $10 \mu \mathrm{M}$ PS- $-\mathrm{NH}_{2}$ for $8 \mathrm{hr}$ (open diamond). II) Loadings of PC1 for pairwise analysis of cytoplasm of exposed cells with the control for 10 $\mu \mathrm{M}$ (red), $5 \mu \mathrm{M}$ (blue) and $2.5 \mu \mathrm{M}$ (black) for $8 \mathrm{hr}$. The dotted line represents the zero ' 0 ' point for each loading. Loadings are offset for clarity. 
Negative features of the loading (unexposed cells) are observed to be richer in protein and lipid content (bands at 1062,1080,1270, 1299 and $1438 \mathrm{~cm}^{-1}$ ). The relatively higher amount of the lipids in unexposed cells compared to PS- $\mathrm{NH}_{2}$ exposed cells can be attributed to damage of the lipidic structures such as lysosomes and membrane bounded cellular compartments upon PS- $\mathrm{NH}_{2}$ exposure. When the nanoparticles are localised inside the lysosomes after $8 \mathrm{hrs}$, they become trapped due to the protonation of their surface in low lysosomal $\mathrm{pH}(\sim 4.5)$. Protonation and the change in the lysosomal $\mathrm{pH}$ cause formation of a gradient for lipids to traffic into the lysosomes from the cytosol and finally the formation of enzymatically unbreakable complexes (Myeloid bodies) ${ }^{26}$. The lipid transfer from cytoplasm to lysosomes and accumulation of lipids in lysosomes, a phenomenon known as lipidosis, causes the loss of lipid related bands in the spectral profile of the cytoplasm. Moreover, later stages of lipidosis cause a distortion and rupture of the lysosomal membrane ${ }^{62-65}$. Therefore, changes in the intensities of the bands at $719 \mathrm{~cm}^{-1}$ (membrane phospholipids), $1270-1301 \mathrm{~cm}^{-}$ ${ }^{1}$ (phospholipids, lipids), $1437 \mathrm{~cm}^{-1}$ (acyl chain of lipids) can be used to track lysosomal damage during nanotoxicological screening of toxic nanoparticles.

As seen in Figure 4, with the exception of the monotonic increase in the nucleic acid related bands at 785 and $810 \mathrm{~cm}^{-1}$, sub lethal doses of PS- $\mathrm{NH}_{2}$, result in significantly different spectral profiles compared to the cells exposed to $10 \mu \mathrm{M}$ PS- $\mathrm{NH}_{2}$. When the concentration of PS- $\mathrm{NH}_{2}$ was reduced to $5 \mu \mathrm{M}$, the exposed cells show increased amounts of lipid, protein and nucleic acid in the cytoplasm compared to unexposed cells (the positive features of loading 1). Also, nucleic acid related bands are prominent at around $1095 \mathrm{~cm}^{-1}\left(\mathrm{PO}_{2}^{-}\right), 1177 \mathrm{~cm}^{-1}(\mathrm{C}$, G) and $1292 \mathrm{~cm}^{-1}(\mathrm{C})$, but are not evident in the $10 \mu \mathrm{M}$ PS- $\mathrm{NH}_{2}$ exposed cells. The $5 \mu \mathrm{M}$ PS$\mathrm{NH}_{2}$ exposed cells also show increases in the intensity of protein $(1030,1208,1250$ and 1654 $\mathrm{cm}^{-1}$ ) and lipid bands $\left(1064 \mathrm{~cm}^{-1}\right)$, compared to unexposed cells. A similar PC Loading profile was observed when the dose was reduced to $2.5 \mu \mathrm{M}$, exhibiting a decrease in the 
intensities of the bands at $785 \mathrm{~cm}^{-1}$ (Nucleic acids), $810 \mathrm{~cm}^{-1}$ (RNA), $1127 \mathrm{~cm}^{-1}$ (U(C-N)), $1266 \mathrm{~cm}^{-1}$ (Amide III ( $\alpha$-helix)), $1319 \mathrm{~cm}^{-1}(\mathrm{G}), 1333 \mathrm{~cm}^{-1}(\mathrm{G})$ and an increase in the intensity of the band at $1655 \mathrm{~cm}^{-1}$ (Amide I). When the respective loadings for each dose are compared, lipid and protein related bands are inverted in going from lethal $(10 \mu \mathrm{M})$ to sub lethal $(2.5 \mu \mathrm{M})$ PS- $\mathrm{NH}_{2}$ doses. The change in the amount of lipid and protein structures with increasing dose can be related to damage of protein and lipid structures as a result of increasing amount of ROS inside the cell for toxic exposures.

Following the effect of dose of $\mathrm{PS}-\mathrm{NH}_{2}$ on A549 cells, the effect of exposure time was monitored by comparing particle exposed cells with their controls. In order to evaluate spectral differences progressively as a function of time, a sub lethal dose of PS- $\mathrm{NH}_{2}(2.5 \mu \mathrm{M})$ was chosen and cells were exposed to the nanoparticles from 4 to $48 \mathrm{hrs}$. Figure 5.I shows the scatter plots of the PCA of spectra corresponding to cytoplasm of exposed and unexposed cells for $24 \mathrm{hr}(2.5 \mu \mathrm{M})$, as a representative example of separation between exposed and unexposed cells. Scatter plots of cytoplasm of exposed and unexposed cells for each exposure time are provided in Supplementary Figure S5. As seen in Figure 5.I, for the case of $24 \mathrm{hr}$, exposed and unexposed cells are largely differentiated according to PC1 (Explained Variance 45\%). Figure 5.II shows the comparison of the loadings of PC1 of cytoplasm of exposed and unexposed cells for 4, 8, 12, 24 and 48 hrs. 


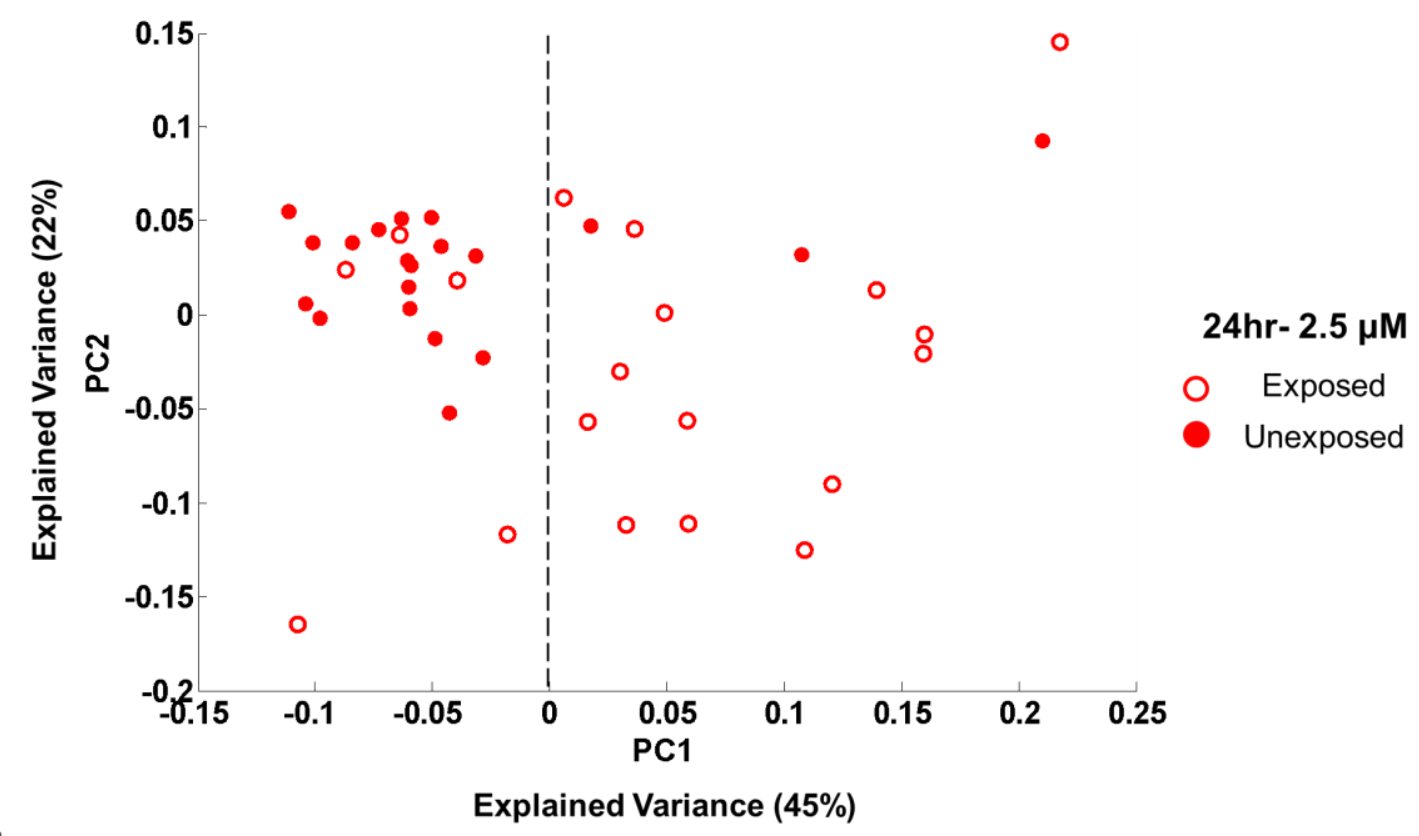

II

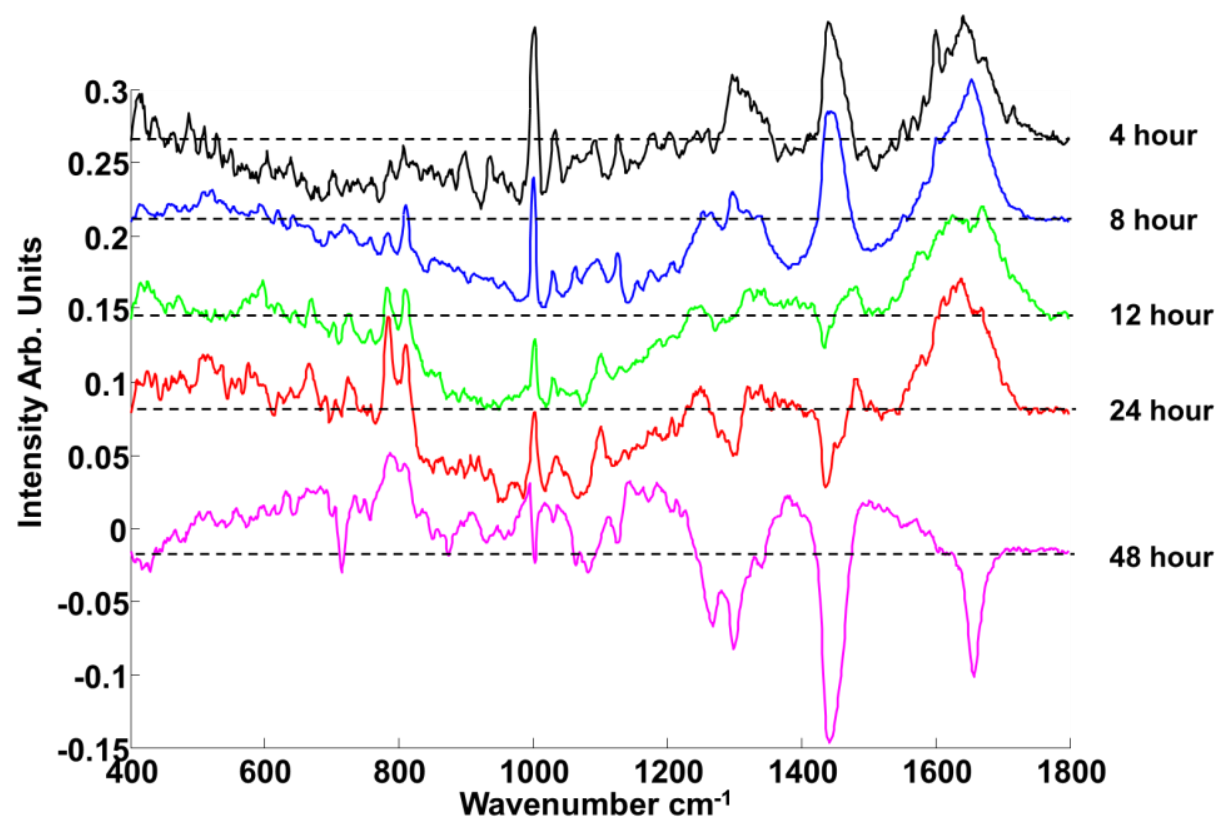

Figure 5. I) Scatter plot of the PCA of spectra corresponding to cytoplasm of the unexposed cells (close circles) and PS- $\mathrm{NH}_{2}$ exposed cells $(2.5 \mu \mathrm{M})$ (open circles) for 4, 8, 12 and $24 \mathrm{hr}$, II) Comparison of the Loading of PC1s for different PS- $\mathrm{NH}_{2}$ concentrations (cytoplasm). 4, 8, 12, 24 and $48 \mathrm{hr}$ are indicated with black, blue, green and magenta red, respectively. Positive features of the PCs are related to exposed cells while negative features of the PCs are 
related to their controls. Loadings are offset for clarity. The dotted line represents the zero ' 0 ' point for each loading.

As in the case of the exposure dose dependent spectral profiles, the evolution of the nucleic acid features at $780 \mathrm{~cm}^{-1}$ and $810 \mathrm{~cm}^{-1}$ is observed to be prominent. However, these features are weak after $4 \mathrm{hr}$ PS- $\mathrm{NH}_{2}$ exposure, and the particle exposed cells differentiate from the unexposed cells largely due to their protein and lipid content. The bands at $1003 \mathrm{~cm}^{-1}$ (Phe), $1602 \mathrm{~cm}^{-1}$ (Phe) and $1640 \mathrm{~cm}^{-1}$ (Amide I) can be attributed to damaged protein structures resulting from the damage in the mRNA template and the distorted proteins accumulate inside the cell as well as normal proteins due to lysosomal damage ${ }^{51}$. The increasing intensity of the lipid bands at 1298 and $1440 \mathrm{~cm}^{-1}$ indicates an increasing amount of lipids in the cytoplasm due to increasing amount of endosomes and lysosomes upon $\mathrm{PS}-\mathrm{NH}_{2}$ exposure. When the time of exposure of the cells to the PS- $\mathrm{NH}_{2}$ is increased to $8 \mathrm{hr}$, following the increases in protein and lipid bands, some changes start to occur in RNA accumulation in the cytoplasm due to the onset of repression of mRNA translation, which are manifest in the Raman spectra of PS-NH 2 exposed cells (positive features of loading 1) as an increase in the band at $810 \mathrm{~cm}^{-1}$. An increase in the intensity of bands at $1319(\mathrm{G}) \mathrm{cm}^{-1}$ and $1333(\mathrm{G}) \mathrm{cm}^{-1}$ can also be observed with increasing exposure time. For this exposure time, the sharp band at $1602 \mathrm{~cm}^{-1}$ (Phe) disappears and the intensity of the $1003 \mathrm{~cm}^{-1}$ band reduces, which can be attributed to the onset of degradation of proteins.

After $12 \mathrm{hr}$ exposure of A549 cells to $\mathrm{PS}-\mathrm{NH}_{2}$, more significant changes occur in the biochemical composition of particle exposed cells compared to previous exposure times. For this exposure time, as seen in Figure 5.II, the nucleic acid band at $785 \mathrm{~cm}^{-1}$ shows an increase in its intensity which indicates the increasing amount of nucleic acids in cytoplasm. Similar to the effect of dose, in the case of increased exposure time, the increase of nucleic acids in the cytoplasm can be observed at $810 \mathrm{~cm}^{-1}$ (RNA), with a larger increase in $785 \mathrm{~cm}^{-1}$ (RNA 
and DNA) compared to $8 \mathrm{hr}$ exposure. Although the increase in the $785 \mathrm{~cm}^{-1}$ band was attributed to RNA accumulation for shorter exposure times (up to $8 \mathrm{hr}$ ), an independent increase is observed on the $785 \mathrm{~cm}^{-1}$ band compared to $810 \mathrm{~cm}^{-1}$ with increasing exposure time, which can be attributed to an increase of DNA content in the cytoplasm. The increasing amount of DNA in the cytoplasm can be attributed to the decay of mitochondrial membrane and release of mitochondrial DNA into the cytoplasm, at this time point. ROS formation and mitochondrial decay affect the spectral profile of proteins and lipids in particle exposed cells and this is reflected in the Raman spectra of unexposed cells and causes the appearance of the bands at $1200-1300 \mathrm{~cm}^{-1}$ (Amide III) and $1438 \mathrm{~cm}^{-1}$ (Protein, Lipids) as negative features of PC1, which represent the unexposed cells. Also notable is the emergence in the loadings spectrum of bands at 1299 and $1438 \mathrm{~cm}^{-1}$. They are both associated with lipid content inside the cytoplasm and the change in the intensity of the bands can be attributed to damage of lipidic structures due to lipidosis after PS- $\mathrm{NH}_{2}$ exposure. The intensity changes in the 1438 $\mathrm{cm}^{-1}$ band can be further used determine cytotoxic events in the cytosol and damage of lysosomes. The band at $1299 \mathrm{~cm}^{-1}$ is progressively reduced until 12 hour particle exposure and becomes inverted for 24 and $48 \mathrm{hr}$ particle exposure, which indicates that lipids are more abundant in unexposed cells compared to exposed ones. The intensity of the band at 1438 $\mathrm{cm}^{1}$ did not show any change up to $8 \mathrm{hr}$, but this band is inverted with increasing intensity from 12 to $48 \mathrm{hr}$, such that it becomes a dominant feature of the discriminating loading. Moreover, the intensity of the $1003 \mathrm{~cm}^{-1}$ (Phe) band reduces significantly, while there is a clear broadening of the Amide I band (1550-1700 $\left.\mathrm{cm}^{-1}\right)$. The intensities of the nucleic acid $\left(785 \mathrm{~cm}^{-1}\right)$ and RNA $\left(810 \mathrm{~cm}^{-1}\right)$ bands increase further for $24 \mathrm{hr}$ exposure, while the protein and lipid bands (1266, 1299 and $\left.1438 \mathrm{~cm}^{-1}\right)$ become more significant as negative features (unexposed cells) of PC1. The further increase in the intensity of the band at $785 \mathrm{~cm}^{-1}$ can be attributed to disruption of membrane structures and release of DNA into the cytoplasm ${ }^{66}$. 
When cells were exposed to $\mathrm{PS}-\mathrm{NH}_{2}$ for $48 \mathrm{hrs}$, the exposed cells are differentiated from unexposed cells according to their nucleic acid content, as the bands at 785 and $810 \mathrm{~cm}^{-1}$ are observed in the positive features of the loading 1 . The band at $1003 \mathrm{~cm}^{-1}$, which indicates the presence of Phe, becomes inverted for the $48 \mathrm{hr}$ exposure. Moreover, the bands at 1299 and $1438 \mathrm{~cm}^{-1}$ become dominant in the negative features of the loading 1 . The change in the lipid bands can be attributed to further decomposition of lipid structures in cell upon longer exposure. Also, the band at $1268 \mathrm{~cm}^{-1}$ appears for this exposure time in the negative features, which indicates a change in the conformational structures of the proteins. The contribution of the Amide I band at $1658 \mathrm{~cm}^{-1}$ has become inverted following $48 \mathrm{hr}$ particle exposure. The inverted bands on loading 1 of PC can be attributed to less abundance of proteins and lipids in particle exposed cells.

The spectra of the cytoplasm of PS- $\mathrm{NH}_{2}$ exposed cells are mainly differentiated from unexposed cells by the intensities of the bands at 785 and $810 \mathrm{~cm}^{-1}$. Moreover, another significant change is observed in the Amide I region of proteins, with increasing exposure time. In order to monitor spectral changes in the Amide I region, the Amide I band (1550$1700 \mathrm{~cm}^{-1}$ ) was analysed separately in detail. Oxidative stress in a cell causes damage in protein structures and changes the protein secondary structure and tertiary conformation. The changes in protein conformations are reflected in the Amide I region of the Raman spectrum. With increasing exposure time, a broadening and shift is observed in the Amide I band. The Amide I band represents the different secondary structures of the proteins, such as $\alpha$-helix, $\beta$ sheet, loops ${ }^{67}$, and the broadening or shift in Amide I band can be attributed to a change in secondary structure of proteins as a result of oxidative stress.

The Amide I region of proteins in the cytoplasm of PS- $\mathrm{NH}_{2}$ exposed cells and changes in the bands upon particle exposure are detailed in Figure 6 and Table 1, for different exposure times (I-V) from 4 to $48 \mathrm{hr}$. The loadings of PC1 of cytoplasm of unexposed and exposed 
cells were used and peak fitting was carried out for all exposure times, using LabSpec Software. As seen in Figure 6, the band at $1602 \mathrm{~cm}^{-1}$, which indicates the presence of Phe, is observed for all exposure times, and a change in the total area of the band is observed as a function of time. The band area increases from 0.51 to 1.88 , from 4 to $12 \mathrm{hr}$ exposure, but then decreases to 0.34 for $24 \mathrm{hr}$ exposure. Following $48 \mathrm{hr}$ exposure, this band has totally disappeared from the positive features of loading 1 . For the first $4 \mathrm{hr}$ particle exposure, both $\alpha$-helix and $\beta$-sheet structures of protein are observed. However, with increasing exposure time, $\alpha$-helix structures become dominant and the bands related to the presence of $\beta$-sheet structure disappear $\left(1674\right.$ and $\left.1679 \mathrm{~cm}^{-1}\right)$. Thus, with increasing exposure, the Amide I band becomes dominated by $\alpha$-helix bands, resulting in an apparent shift to lower wavenumbers up to $24 \mathrm{hr}$ exposure. When cells are exposed to the $\mathrm{PS}-\mathrm{NH}_{2}$ for $48 \mathrm{hrs}$, the Amide I band becomes completely inverted and a sharp band at $1658 \mathrm{~cm}^{-1}$ (Amide I, $\alpha$-helix) is observed in the negative features of the loading $1^{48-50}$. 


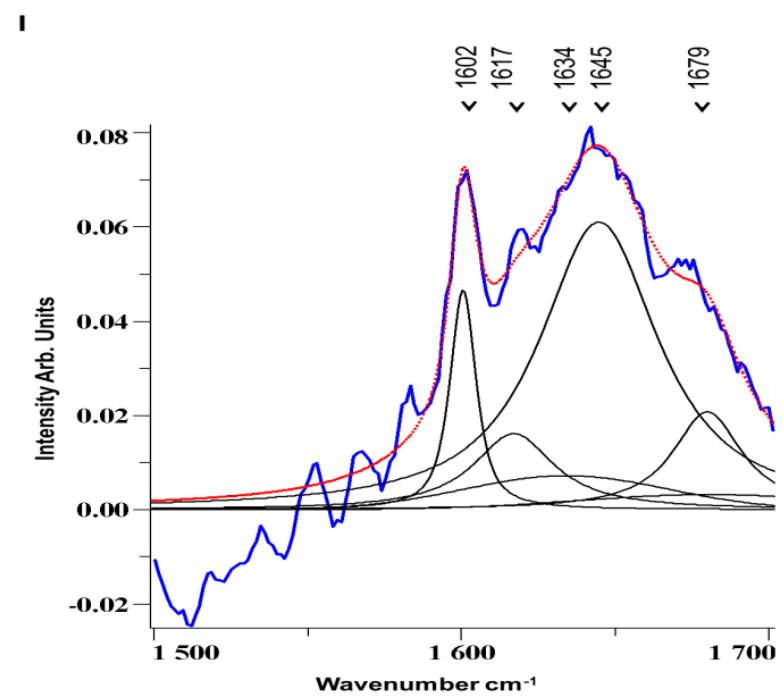

II
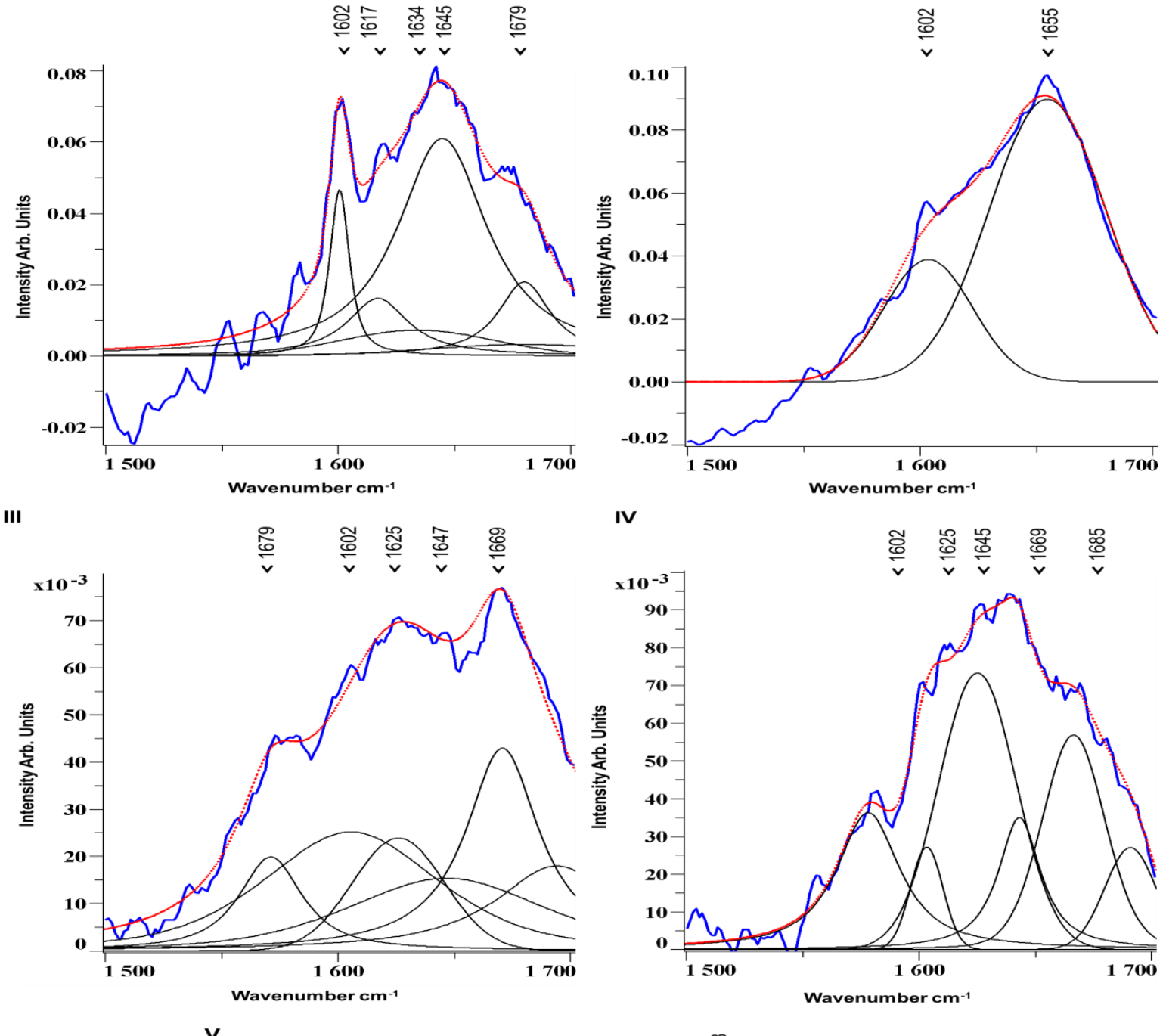

IV
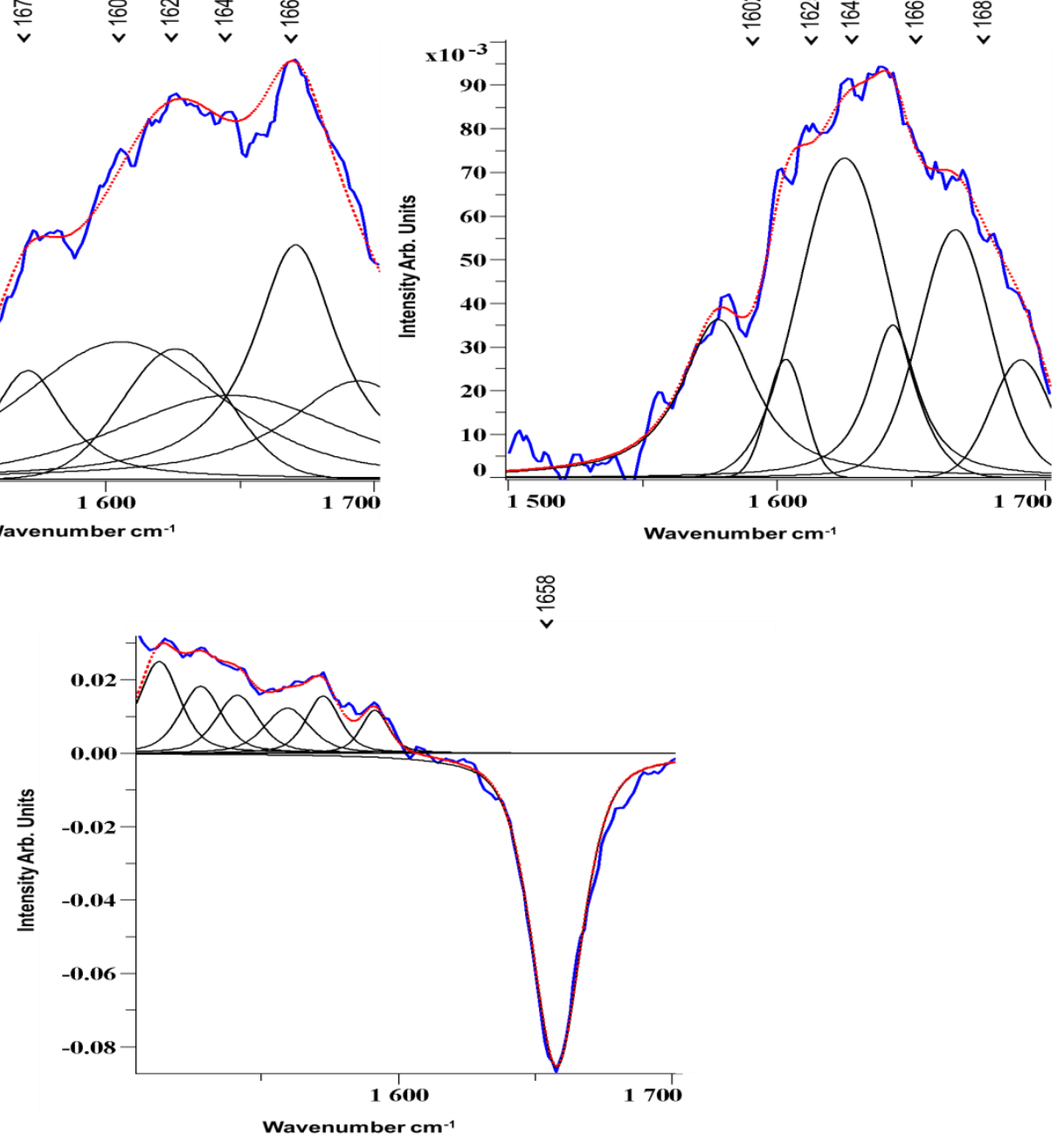

Figure 6. Comparison of the changes in the Amide I region of loading 1 for 4 (I), 8 (II), 12 (III), 24 (IV) and 48 (V) hrs. The loadings and sum of the bands after fitting are indicated 
with blue and red lines, respectively. Each individual fitted band is represented by black lines. Peak positions are indicated on the top of the fitted figures.

Table 1. Assignments of Raman Bands of proteins in Amide I Region ${ }^{47-49,68}$.

\begin{tabular}{|c|c|c|c|}
\hline & & $\frac{\text { Band Positions (1550-1700 }}{\underline{\left.\mathrm{cm}^{-1}\right)}}$ & Band Assignments \\
\hline & & 1602 & Phe \\
\hline & & 1618 & $\operatorname{Trp}, \operatorname{Tyr}(\delta(C=C)$ stretch. $)$ \\
\hline & & 1634 & $\begin{array}{c}\text { Amide I } \\
\text { (Both } \alpha \text {-helix and } \beta \text { sheet) }\end{array}$ \\
\hline & 4 hour & 1645 & $\begin{array}{l}\text { Amide I } \\
(\alpha \text {-helix })\end{array}$ \\
\hline & & 1679 & $\begin{array}{l}\text { Amide I } \\
(B \text { sheet })\end{array}$ \\
\hline 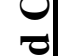 & & 1602 & Phe \\
\hline : & 8 hour & 1655 & $\begin{array}{l}\text { Amide I } \\
(\alpha \text {-helix })\end{array}$ \\
\hline 视 & & 1569 & $\begin{array}{c}\text { Trp } \\
\text { (Indole Ring) }\end{array}$ \\
\hline ஜ் & & 1602 & Phe \\
\hline & 12 hour & 1625 & Trp \\
\hline & & 1647 & Random coils \\
\hline & & 1669 & $\begin{array}{l}\text { Amide I } \\
(\alpha \text {-helix })\end{array}$ \\
\hline & & 1582 & Phe \\
\hline & & 1602 & Phe \\
\hline & & 1625 & Trp \\
\hline & 24 bou & 1645 & $\alpha$-helix \\
\hline & $2+$ noul & 1669 & Amide I $(\mathrm{C}=\mathrm{O})$ \\
\hline & & 1685 & $\begin{array}{c}\text { Amide I (disordered structure; non } \\
\text { hydrogen } \\
\text { bonded) }\end{array}$ \\
\hline & $48 \mathrm{hr}$ & 1658 & Amide I (inverted) \\
\hline
\end{tabular}


Time and dose dependent cytotoxicity can be seen as a 3D response surface rather than a $2 \mathrm{D}$ curve, due to the variance of molecular determinants forming overall cytotoxicity ${ }^{41}$. Thus, sublethal concentrations can elicit a similar effect to higher concentrations at different timepoints. Figure 7 shows the comparison of loading 1 of PC of cytoplasm of unexposed and exposed cells for cytoplasm for $8 \mathrm{hr}$ exposure $10 \mu \mathrm{M}$ and $48 \mathrm{hr}$ exposure $2.5 \mu \mathrm{M}$ PS- $\mathrm{NH}_{2}$. Both loadings show similar positive (exposed cells) and negative features (unexposed cells), with the possible exception of the band at $810 \mathrm{~cm}^{-1}$ which indicates the presence of accumulated noncoding RNA in the cytoplasm. This difference can be explained by the more acute toxic effect of repression of translation of mRNA of higher exposure doses. More molecular determinants of toxicity are manifest for the nucleic acid constituents for all exposure times, although more prominantly for high doses and long exposure times. For this reason, the difference in the bands related to nucleic acids can be attributed to changing amounts of molecular determinants. Compared to their controls, exposed cells showed lower contributions of protein and lipids, which can be attributed to damage to these biochemical constituents in particle exposed cells due to oxidative attack. 


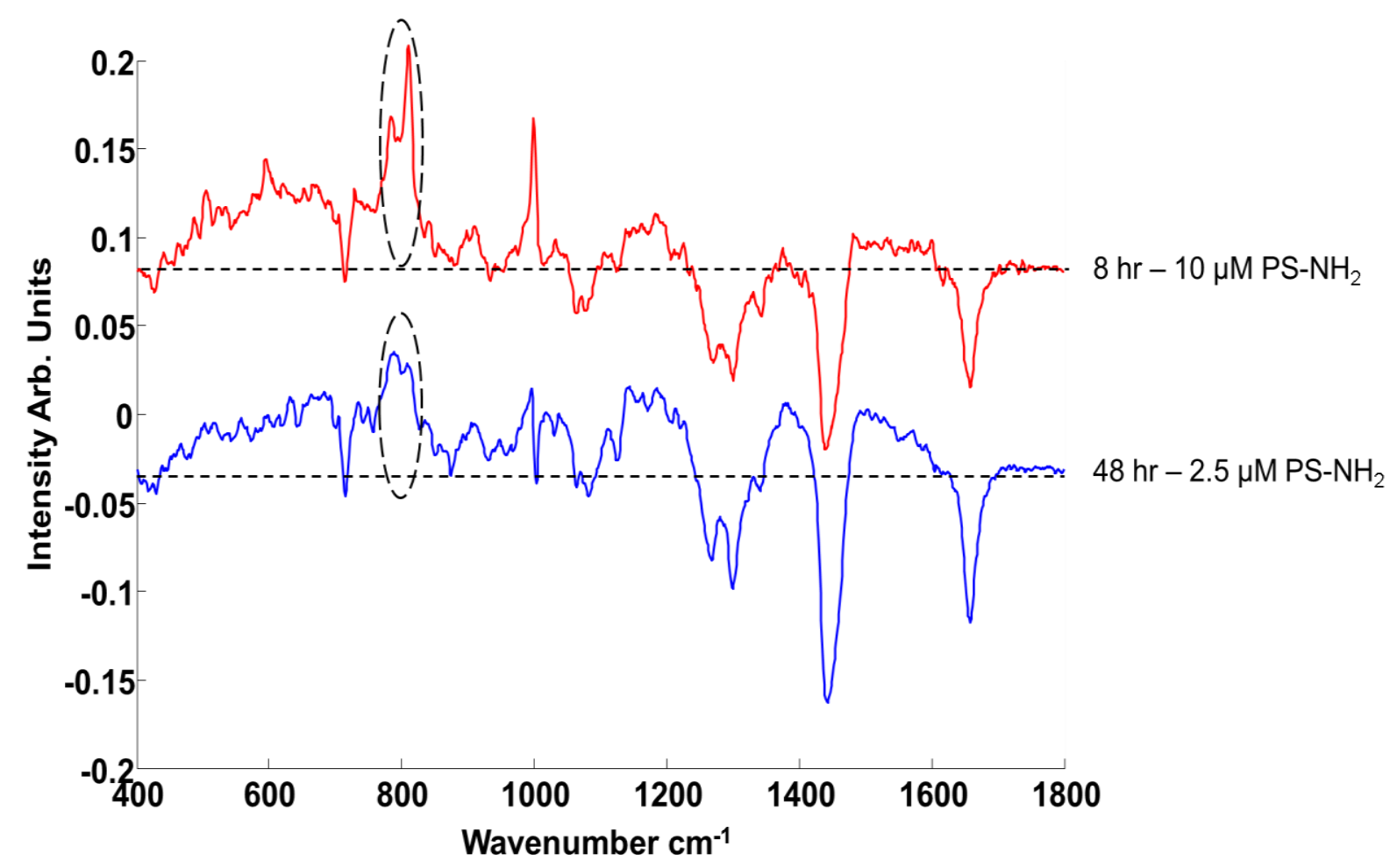

Figure 7. Comparison of the Loading 1 of PCs of cytoplasm for exposed and unexposed cells after $8 \mathrm{hr}$ exposure to $10 \mu \mathrm{M}$ (red) and $48 \mathrm{hr} 2.5 \mu \mathrm{M}$ (blue) PS- $\mathrm{NH}_{2}$. Positive and negative features of the loadings relate to exposed and unexposed cells, relatively. The significant differences between the loadings are indicated with black circles. Loadings are offset for clarity. The dotted line represents the zero '0' point for each loading.

As shown in Figure 2, comparatively fewer changes are observable in the spectral signature of the nucleus and nucleolus, as might be expected, given the uptake and trafficking of the $\mathrm{PS}-\mathrm{NH}_{2}$ is through the cytoplasm, over a period of up to $24 \mathrm{hrs}$. No localisation of PS-HN 2 nanoparticles in the nucleus has been reported and, indeed, it has been seen that neutral PS nanopatricles are stored in lysosomal vesicles over several passages of the cells ${ }^{33,69}$. Nevertheless, as shown in Figure 8, the mean difference spectrum of the nuclear region does show indications of reduced contributions of nucleic acids at 785 and $810 \mathrm{~cm}^{-1}$, after $24 \mathrm{hr}$ 
exposure, consistent with leakage of nuclear material into the cytoplasm after the onset of apoptosis. This is also consistent with the larger increase of nucleic acid features in cytoplasm of PS- $\mathrm{NH}_{2}$ exposed cells after $24 \mathrm{hr}$ exposure (Figure 5.II).

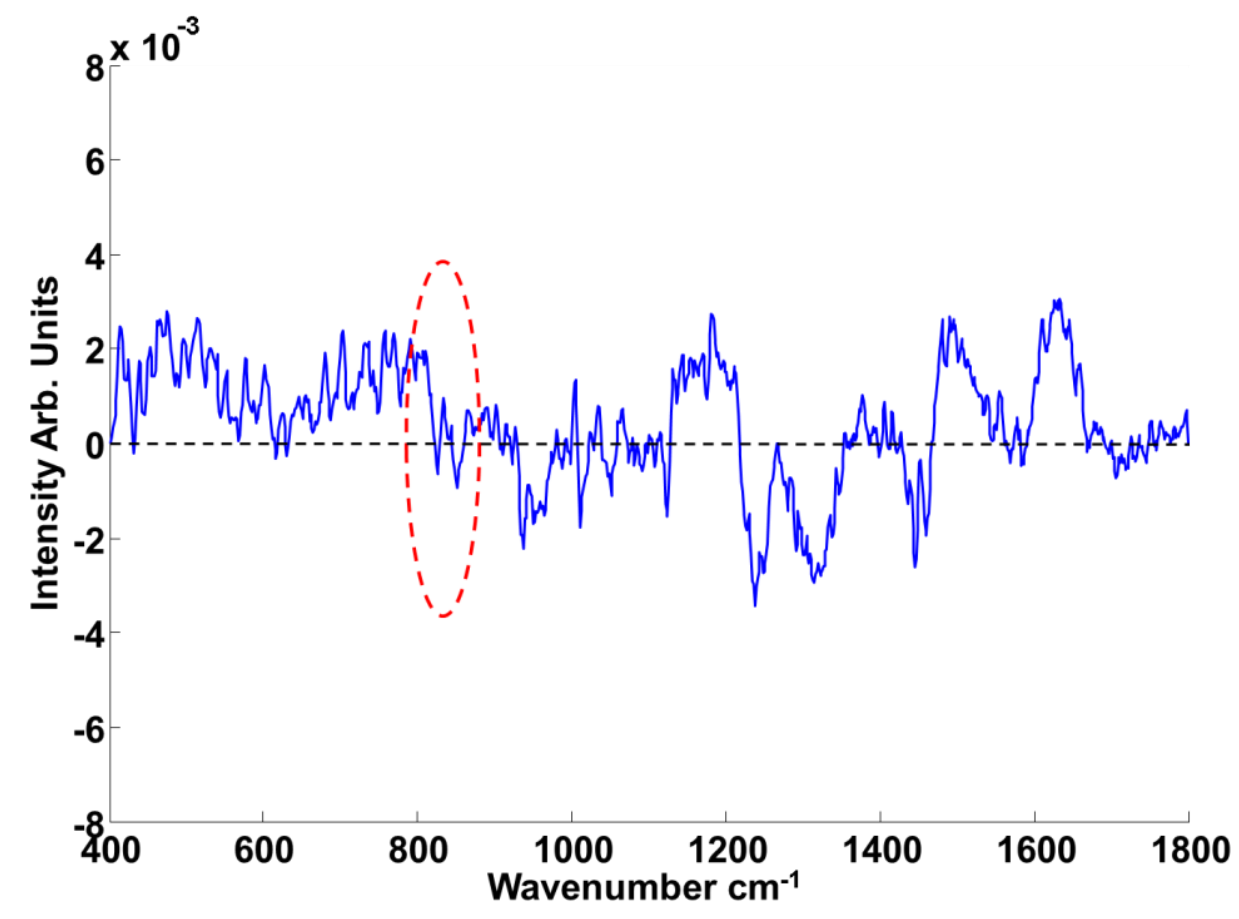

Figure 8. Difference spectrum of nucleus of $\mathrm{PS}-\mathrm{NH}_{2}$ exposed cells and unexposed cells obtained by subtraction of mean spectra of $24 \mathrm{hr}$ PS- $\mathrm{NH}_{2}$ exposed cells from mean spectra of unexposed cells.

In the case of exposure to the PS- $\mathrm{NH}_{2}$, the most significant changes are observed in the cytoplasm, as expected due to the uptake mechanism and cellular trafficking of the $\mathrm{PSNH}_{2}$. The uptake mechanism by endocytosis and subsequent cellular trafficking initiates a series of molecular events and hence molecular determinants of the cytotoxicity. In endocytosis, toxic PS- $\mathrm{NH}_{2}$ particles are carried to lysosomes by endosomes resulting in lipidosis, lysosomal membrane rupture and ROS in the cytosolic region. The mitochondria of the particle exposed cells are affected as a result of cytosolic changes and mediate the release of pro-inflammatory factors as signals of cytotoxicity. On the other hand, for example doxorubicin, commonly 
used anti-cancer chemotherapy drug, is taken into cells by passive diffusion and targets the nuclear region directly. The cytotoxic effects are manifest initially in the nuclear and nucleolar regions of the cell, and only later in the cytoplasm ${ }^{16}$. The process is inverse for PS$\mathrm{NH}_{2}$, whereby the toxic effects of the particles are initially seen in the cytoplasmic region for shorter exposure times, although changes in the nuclear area may be more significant in chronic exposures, and linked with genotoxic effects.

In this study, the cytoplasmic changes relating to molecular events upon particle exposure due to the uptake mechanism and cellular trafficking the $\mathrm{PS}-\mathrm{NH}_{2}$, have been evaluated in a dose and time dependent manner, using Raman spectroscopy. The established initial response of oxidative stress is not evident in the spectral response, however. ROS such as hydrogen peroxide $\left(\mathrm{H}_{2} \mathrm{O}_{2}\right)$, superoxide anion $\left(\mathrm{O}_{2}^{-\cdot}\right)$ and hydroxyl radicals $\left(\mathrm{HO}^{*}\right)$ are known to be Raman inactive and, in addition, they are consumed rapidly after initial generation ${ }^{46,70}$. Nevertheless, although the molecular signatures of ROS are not possible to identify with Raman spectroscopy, the signatures of the resultant oxidative stress can be monitored via the signatures of the changes in biochemical constituent of the cells. Oxidative stress in the cytoplasm triggers a complex cascade of events which can include mitochondrial membrane potential decay, caspase activation, apoptosis and ultimately cell death. For a more extensive discussion of the responses, see for example references 29 and 41. The Raman spectral biomarkers of ROS formation, lysosomal damage and biochemical composition changes upon nanoparticle exposure are identified and the most dominant features changing inside the cytoplasm of the cells upon particle exposure are determined to be the bands at 785 and 810 $\mathrm{cm}^{-1}$ which can be attributed to nucleic acids inside the cytosol. It is notable, however, that the spectral changes are dominated by the 785 and $810 \mathrm{~cm}^{-1}$ bands, rather that the whole spectrum of RNA or DNA ${ }^{71}$, suggesting that the spectral signature is due to conformational changes in the nucleic acid structures due to change in the environment rather than 
production or consumption of the nucleic material. Especially for sub-lethal doses of PS-NH some contributions are observed to the spectra of cells which indicate a higher protein content compared to control cells. Cells use a recovery mechanism to stabilize the increased ROS levels inside the cells upon exposure to a toxicant ${ }^{46}$. Increased production of enzymes such as superoxide dismutase, catalase, glutathione peroxidase, glutathione reductase, causes an increase in protein related bands. For this reason, the changes in cytosolic acids followed by increased protein profile can be attributed to increased ROS levels and the Raman profile can be used as a Nanotoxicological assay biomarker for a wide variety of nanomaterials.

In comparison with the responses of the classical cytotoxic assays, (Figure 1.II), significant spectral changes are observed over a dose range (from 2.5 to $10 \mu \mathrm{M}$ ), in which MTT shows no change, but $\mathrm{AB}$ shows significant change. These spectroscopic changes are therefore better correlated with $\mathrm{AB}$, consistent with an interpretation of origin in cytosolic RNA which subsequently accumulates around the mitochondria. The changes in 1299 and $1438 \mathrm{~cm}^{-1}$ bands, which are associated with the later stage toxic response and become inverted after 12 $\mathrm{hr}$ particle exposure with an increasing intensity in the negative features of the loading 1, may be better correlated with the MTT response and therefore mitochondrial decay (Figure 5.2). Mitochondrial ROS production can cause significant oxidative stress, damaging protein and lipid structures and mediating the release of factors to initiate the apoptotic process.

Spectral changes, as elucidated by PCA, are complex combinations of contributions of the multitude of biomolecules involved in the cellular responses. However, the combination signature shows consistency in its evolution as a function of time and dose, and correlates well with the known cytotoxic responses. Therefore, not individual spectra, but signatures at $785 \mathrm{~cm}^{-1}$ (either RNA or DNA), $810 \mathrm{~cm}^{-1}$ (RNA), $1299 \mathrm{~cm}^{-1}$ (lipids) and $1435 \mathrm{~cm}^{-1}$ (lipids) and proteins Amide I (1550-1700 $\left.\mathrm{cm}^{-1}\right)$ region can be a guide to nanotoxicological screening. 


\section{Conclusion}

Classical colorometric cytotoxicological assays monitor a single endpoint by which the cellular response to a toxicant is quantified in terms of the $\mathrm{IC}_{50}$. The response is, however, a complex cascade of events, and different assays can report significantly different viability results, and yield little information about the mechanisms of response. The use of a label-free and rapid technique which provides multiparametric information about the changes in the biomolecular structures such as proteins, lipids and nucleic acids following exposure to a toxicant can accelerate the toxicological screening of nanomaterials. This study has identified spectral signatures which are correlated with nanoparticle exposure dose and time, and therefore the known mechanisms of cellular response and toxicity, demonstrating the potential of Raman spectroscopy as a label-free technique to provide multi-parametric information about the biomolecular changes upon a toxicant exposure. It is demonstrated that spectral profiles of the particle exposed cells can be used to track the fingerprint of the molecular responses. Time and dose dependent cytotoxic responses and their reflection to the biochemical fingerprint of the cells can be monitored by using Raman spectroscopy in a progressive way. For all exposure times and doses, the most prominent Raman spectral marker, reflecting the cytotoxic response to exposure to model $\mathrm{PS}-\mathrm{NH}_{2}$ nanoparticles, is found to be the bands at 785 and $810 \mathrm{~cm}^{-1}$ in the cytoplasm, reflecting changes in cytoplasmic nucleic acid content. Notably, this response is not normally identified by conventional cytotoxicity assays. The concomitant and subsequent changes in the intensity of the bands corresponding to proteins (Amide I region (1550-1700 $\mathrm{cm}^{-1}$ ) and lipids (1229 and $1438 \mathrm{~cm}^{-1}$ ) can also be used to determine toxic effect of nanoparticles. The use of Raman spectroscopy helps to corroborate and further elucidate the mechanism of action of the nanoparticles within 
cells and Raman cytotoxicity spectral-markers identified for model nanoparticles can potentially be used to screen for the mode of action and degree of toxicity of novel nanoparticles, in a single label-free assay.

\section{Acknowledgement}

This work was supported by Science Foundation Ireland Principle Investigator Award 11/PI/1108

\section{References}

1. Consumer Products Inventory, at http://www.nanotechproject.org/cpi/, (accessed June 2016).

2. G. Oberdörster, E. Oberdörster and J. Oberdörster, Environ Health Perspect., 2005, 113, 823-839.

3. T. J. Webster, Int J Nanomedicine, 2006, 1, 115-116.

4. K. Donaldson, V. Stone, C. L. Tran, W. Kreyling and P. J. Borm, Occup. Environ. Med., 2004, 61, 727-728.

5. OECD (2013) OECD Guidelines for the Testing of Chemicals, http://www.oecd.org/chemicalsafety/testing/oecdguidelinesforthetestingofchemicals.htm, (accessed December 2015).

6. W. T. Godbey, K. K. Wu and A. G. Mikos, Proc. Natl. Acad. Sci. U.S.A., 1999, 96, $5177-5181$ 
7. G. Tosi, B. Bortot, B. Ruozi, D. Dolcetta, M. A. Vandelli, F. Forni and G. M. Severini, Curr Med Chem, 2013, 20, 2212-2225.

8. H. J. Byrne, G. Sockalingum and N. Stone, in Biomedical Applications of Synchrotron Infrared Microspectroscopy, ed. D. Moss, Royal Society of Chemistry, RCS Analytical Spectroscopy Monographs, Cambridge, no. 11, 2011, 4, 105-142.

9. J. R. Ferraro and K. Nakamoto, Introductory Raman Spectroscopy, Academic Press, Orlando, 1994.

10. A. G. Walton, M. J. Deveney and J. L. Koenig, Calcified Tissue Research, 1970, 6, 162167.

11. G. J. Puppels and J. Breve, in Biomedical Applications of Spectroscopy, ed. R. J. H. Clark and R. E. Hester, Wiley, Chichester, 1996, 1, 1-47.

12. F. Bonnier, F. Petitjean, M. J. Baker and H. J. Byrne, Journal of Biophotonics, 2014, 7, 167-179.

13. F. Bonnier, A. Mehmood, P. Knief, A. D. Meade, W. Hornebeck, H. Lambkin, K. Flynn, V. McDonagh, C. Healy, T. C. Lee, F. M. Lyng and H. J. Byrne, Journal of Raman Spectroscopy, 2011, 42, 888-896.

14. J. Dorney, F. Bonnier, A. Garcia, A. Casey, G. Chambers, and H. J. Byrne, Analyst, 2012, 137, 1111-1119.

15. E. Efeoglu, M. Keating, J. McIntyre, A. Casey and H. J. Byrne, Anal. Methods, 2015, 7, $10000-10017$.

16. Z. Farhane, F. Bonnier, A. Casey and H. J. Byrne, 2015, Analyst, 140, 4212-4223. 
17. Z. Farhane, F. Bonnier, M. A. Maher, J. Bryant, A. Casey and H. J. Byrne, J Biophotonics, 2016, 1-15 / DOI 10.1002/jbio.201600019.

18. H. Nawaz, F. Bonnier, P. Knief, O. Howe, F. M. Lyng, A. D. Meade and H. J. Byrne, Analyst, 2010, 135, 3070-3076.

19. H. Nawaz, F. Bonnier, A. D. Meade, F. M. Lyng and H. J. Byrne, Analyst, 2011, 136, $2450-2463$.

20. H. Nawaz, A. Garcia, A. D. Meade, F. M. Lyng and H. J. Byrne, Analyst, 2013, 138, $6177-6184$.

21. C. A. Owen, J. Selvakumaran, I. Notingher, G. Jell, L. L. Hench and M. M. Stevens, J Cell Biochem, 2006, 99, 178-186.

22. A. Zoladek, F. C. Pascut, P. Patel and I. Notingher, Journal of Raman Spectroscopy, $2011,42,251-258$.

23. T. Chernenko, C. Matthäus, L. Milane, L. Quintero, M. Amiji and M. Diem, ACS nano, 2009, 3, 3552-3559.

24. M. E. Keating, F. Bonnier and H. J. Byrne, Analyst, 2012, 137, 5792-5802.

25. P. Knief, C. Clarke, E. Herzog, M. Davoren, F. M. Lyng, A. D. Meade and H. J. Byrne, Analyst, 2009, 134, 1182-1191.

26. S. Anguissola, D. Garry, A. Salvati, P. J. O’Brien and K. A. Dawson, PLoS ONE, 2014, 9, e108025. 
27. O. Lunov, T. Syrovets, C. Loos, J. Beil, M. Delacher, K. Tron, G. U. Nienhaus, A. Musyanovych, V. Mailänder, K. Landfester and T. Simmet, ACS Nano, 2011, 5, 16571669.

28. O. Lunov, T. Syrovets, C. Loos, G. U. Nienhaus, V. Mailänder, K. Landfester, M. Rouis and T. Simmet, ACS Nano, 2011, 5, 9648-9657.

29. T. Xia, M. Kovochich, M. Liong, J. I. Zink and A. E. Nel, ACS Nano, 2008, 2, 85-96.

30. P. Ruenraroengsak, P. Novak, D. Berhanu, A. J. Thorley, E. Valsami-Jones, J. Gorelik, Y. E. Korchev and T. D. Tetley, Nanotoxicology, 2012, 6, 94-108.

31. F. Wang, L. Yu, M. P. Monopoli, P. Sandin, E. Mahon, A. Salvati and K. A. Dawson, Nanomedicine, 2013, 9, 1159-1168.

32. L. Treuel, X. Jiang and G. U. Nienhaus, J R Soc Interface, 2013, 10, 20120939.

33. K. Shapero, F. Fenaroli, I. Lynch, D. C. Cottell, A. Salvati and K. A. Dawson, Mol BioSyst, 2011, 7, 371-378.

34. Q. Mu, N. S. Hondow, L. Krzemiński, A. P. Brown, L. J. Jeuken and M. N. Routledge, Part Fibre Toxicol, 2012, 9, 29.

35. M. G. Bexiga, J. A. Varela, F. Wang, F. Fenaroli, A. Salvati, I. Lynch, J.C. Simpson and K. A. Dawson, Nanotoxicology, 2011, 5, 557-567.

36. M. Miljkovic, T. Chernenko, M. J. Romeo, B. Bird, C. Matthaus and M. Diem, Analyst, 2010, 135, 2002-2013.

37. M. V. Berridge, P. M. Herst and A. S. Tan, Biotechnol Annu Rev, 2005, 11, 127-152.

38. S. N. Rampersad, Sensors, 2012, 12. 
39. E. Vega-Avila and M. K. Pugsley, Proc West Pharmacol Soc, 2011, 54, 10-14.

40. D. Ragnvaldsson, R. Berglind, M. Tysklind and P. Leffler, Ambio, 2007, 36, 494-501.

41. M. A. Maher, P. C. Naha, S. P. Mukherjee and H. J. Byrne, Toxicology In Vitro, 2014, 28, $1449-1460$.

42. M. J. White, M. J. DiCaprio and D. A. Greenberg, J Neurosci Methods, 1996, 70, 195200.

43. J. O'Brien, I. Wilson, T. Orton and F. Pognan, Eur J Biochem, 2000, 267, 5421-5426.

44. T. Mosmann, J Immunol Methods, 1983, 65, 55-63.

45. S. P. Mukherjee, N. O'Claonadh, A. Casey and G. Chambers, Toxicol In Vitro, 2012, 26, $238-251$.

46. L. Casteilla, M. Rigoulet and L. Penicaud, IUBMB Life, 2001, 52, 181-188.

47. T. P. Pobezhimova and V. K. Voinikov, Membr Cell Biol, 2000, 13, 595-602.

48. I. Notingher, S. Verrier, S. Haque, J. M. Polak and L. L. Hench, Biopolymers, 2003, 72, $230-240$.

49. I. Notingher and L. L. Hench, Expert Rev Med Devices, 2006, 3, 215-234.

50. Z. Movasaghi, S. Rehman and I. U. Rehman, Applied Spectroscopy Reviews, 2007, 42, 493-541.

51. E. Fröhlich, C. Meindl, E. Roblegg, B. Ebner, M. Absenger and T. R Pieber, Fibre Toxicol, 2012, 9, 26.

52. C. Loos, T. Syrovets, A. Musyanovych, V. Mailänder, K. Landfester, G. U. Nienhaus and T. Simmet, Beilstein Journal of Nanotechnology, 2014, 5, 2403-2412. 
53. M. Ekkapongpisit, A. Giovia, C. Follo, G. Caputo and C. Isidoro, Int J Nanomedicine, $2012,7,4147-4158$.

54. E. W. Small and W.L. Peticolas, Biopolymers, 1971, 10, 69-88.

55. G. J. Thomas, G. C. Medeiros and K. A. Hartman, Biochemical and Biophysical Research Communications, 1971, 44, 587-592.

56. A. Ghita, F. C. Pascut, M. Mather, V. Sottile and I. Notingher, Anal Chem, 2012, 84, 3155-3162.

57. P. Ruenraroengsak and T. D. Tetley, Part Fibre Toxicol, 2015, 12, 19.

58. T. Xia, M. Kovochich, J. Brant, M. Hotze, J. Sempf, T. Oberley, C. Sioutas, J. I. Yeh, M. R. Wiesner and A. E. Nel, Nano Lett, 2006, 6, 1794-1807.

59. M. Saikia, D. Krokowski, B. J. Guan, P. Ivanov, M. Parisien, G. F. Hu, P. Anderson, T. Pan and M. Hatzoglou, J Biol Chem, 2012, 287, 42708-42725.

60. S. Yamasaki, P. Ivanov, G. F. Hu and P. Anderson, J Cell Biol, 2009, 185, 35-42.

61. A. Czech, S. Wende, M. Mörl, T. Pan and Z. Ignatova, PLoS Genet, 2013, 9, e1003767.

62. H. Lüllmann, R. Lüllmann-Rauch and O. Wassermann, Biochem Pharmacol, 1978, 27, 1103-1108.

63. N. D. Sonawane, J. R. Thiagarajah, and A. S. Verkman, J Biol Chem, 2002, 277, 55065513.

64. D. Drenckhahn, L. Kleine and R. Lüllmann-Rauch, Lab invest, 1976, 35, 116-123.

65. A. Asokan and M. J. Cho, J Pharm Sci, 2002, 91, 903-913.

66. S. Elmore, Toxicol Pathol, 2007, 35, 495-516. 
67. B. H. Stuart, Biological Applications of Infrared Spectroscopy, ACOL Series, Wiley, Chichester, UK, 1997.

68. A. Rygula, K. Majzner, K. M. Marzec, A. Kaczor, M. Pilarczyk and M. Baranska, Journal of Raman Spectroscopy, 2013, 44, 1061-1076.

69. A. Salvati, C. Åberg, T. dos Santos, J. Varela, P. Pinto, I. Lynch and K. A. Dawson, Nanomedicine NBM, 2011, 7, 818-826.

70. S. P. Mukherjee and H. J. Byrne, Nanomedicine NBM, 2012, 9, 202-211.

71. F. Bonnier, P. Knief, B. Lim, A. D. Meade, J. Dorney, K. Bhattacharya, F. M. Lyng and H. J. Byrne, Analyst, 2010, 135, 3169-3177. 